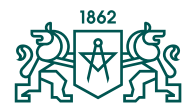

RIGA TECHNICAL UNIVERSITY
No. 5, Sept. 2021, pp. 31-64 https://doi.org/10.7250/HESIHE.2021.003

\title{
ACTIVITIES OF ĀGENSKALNS GYMNASTICS AND SPORTS SOCIETY AND ITS HEADQUARTERS AT 7 BALDONES STREET
}

RITA APINE*

Latvian Sport Museum

Summary. Ägenskalns Gymnastics and Sports Society was one of the largest and best-known Baltic-German sports organizations in the first half of the 20 th century. Sports enthusiasts of various professions, including engineers, participated in the activities of this society. The house built by the Society in 1910 at 7 Baldones Street, Riga, which has been rebuilt several times, played an important role in the sports life. The research presents comprehensive documentary evidence about the Society until the repatriation of the BalticGermans in 1939 and the history of its headquarters building. Using the documents and press materials from the Latvian State Historical Archive (LSHA) of the National Archives of Latvia (NAL), archive documents of the Riga Construction Board, as well as the collection of the Latvian Sports Museum, previously unknown facts have been revealed.

Keywords: Āgenskalns Gymnastics and Sports Society, 7 Baldones Street, architects: Leopolds Rïmers, Haralds Blaus, Alfrēds Laukirbe.

\section{Introduction}

In the second half of the 19th century, sports in the modern understanding of the concept flourished in the provinces of Kurzeme and Vidzeme, which were part of the Tsarist Russia at that time [1]. All sports disciplines known in Scandinavia and Western Europe were known and exercised. From the middle of the 19th century until World War I, there were about 160 sports organizations in the Baltic provinces, and more than 90 were located in the territory of Latvia.

\footnotetext{
* Corresponding author.

E-mail: rita.apine@sportamuzejs.lv 
The beginnings of sports life in the Baltic provinces were shaped by the traditions of the German nobility and the mentality of the BalticGermans. Under the influence of the German culture, the gymnastics movement began in the 1830s, which overtook Western Europe at the turn of the 19th century. Sports societies demonstrated a growing interest in gymnastics and suggested introducing it at schools in the form of games and physical exercises.

The Baltic-Germans, who had been educated at the German schools and sports institutes and later came to the Baltic provinces were the pioneers of sports movement in Latvia.

In the 19th century, gymnastics societies established in Reval (at present - Tallinn) in 1819, in Riga in 1862, in Dorpat (at present - Tartu) in 1864, and in Liepāja in 1885 became gymnastics centres in the Baltics.

In the spring of 1862, a German Wilhelm Wahrbandt (1837-1894) together with the like-minded people founded the first gymnastics society in Latvia - Riga Gymnastics Society (RGS; Rigaer Turnverein). The students and lecturers of Riga Polytechnicum (RP), and from 1896 - Riga Polytechnic Institute (RPI) also participated in the work of the society as its members.

In 1881, an Italian Renaissance-style stone building with a modern gym was built next to Riga City Vocational School in Nikolaja Boulevard (at present - K. Valdemāra Street) based on the design of the City Architect of Riga (1879-1915) Reinhold Schmaehling (1840-1917) [2].

Inspired by the RGS and encouraged by the like-minded people, the Baltic-Germans started a gymnastic movement on the left bank of the Daugava - in Ägenskalns and its surroundings at the beginning of the 20th century. Sports life was formed and stated to develop thanks to four strong Baltic-Germans sports organizations Ägenskalns Slide Society (Hagensberger Rodelverein) founded in 1896, $\bar{A}$ genskalns Gymnastics and Sports Society ( $\bar{A} G S S$; Hagensberger Turn- und Sport-verein) founded in 1903; Ägenskalns Rifle Society (Hagensberger Schutzengesellschaft zu Riga) founded in 1907, and $\bar{A}$ genskalns Sociable Society (Hagensberger Geselliger Verein) founded in 1896.

The aim of the present research is to study the activities and role of the German Ägenskalns Gymnastics and Sports Society and the role engineers played in the work of the Society; the history of the Society's headquarters and the participation of architects in its creation, as well as to assess the contribution of the Society to the development of sport in Latvia in the early 20th century and in the Republic of Latvia (19181940). The research was performed using hermeneutics, source and literature research methods. 


\section{Sport in Āgenskalns until World War I}

Since 1880, Ägenskalns Park with the Summer Theatre in Riga at 11 Kalnciema Street, Pārdaugava, in the then Jelgava Suburb, belonged to Georg Johannes Ebert (1850-1920) [3; p. 34]. Long before the founding of the $\bar{A} G S S$ and the construction of its gym, the Ebert Restaurant in Ägenskalns Park was established as a public gym. The place with a large hall in a large wooden building, a skittle-alley, a shooting range and a beautiful garden for gymnastics and sports was very attractive [4; p. 55]. The gymnastics exercises took place on Monday and Thursday evenings from eight to ten o'clock [3; p. 278]. The headquarters of Ägenskalns Sociable Society at 15 Baložu Street, where gymnastics performances often complemented various events, was the second support point of gymnastics. On 11 May 1903, the first meeting of the Gymnastics Department was held in the premises of the Society [5]. The Department had decided to become an independent society [6] and later named itself the Ägenskalns Gymnastics and Sports Society. The Statutes of the new Society were approved on 7 November 1903. The aim of the Society was to unite people to teach them to exercise properly, ride a bicycle, skate, swim, learn different sports and develop themselves. In the name of this noble aim, it was planned to equip closed and open spaces where people could not only do sports, but also master the technical structure of sports equipment, where competitions, entertainment events and games allowed by law, except for card games, could be organised. The statutes stipulated that during trips and competitions, members should wear the uniform of the Society with the distinctive sign of the uniform headgear - cockades and a ribbon on the sleeve. The structure of the sports society was approved by the local governor [7; p. 15].

Figure 1. Logo of Āgenskalns Gymnastics and Sports Society (1918).

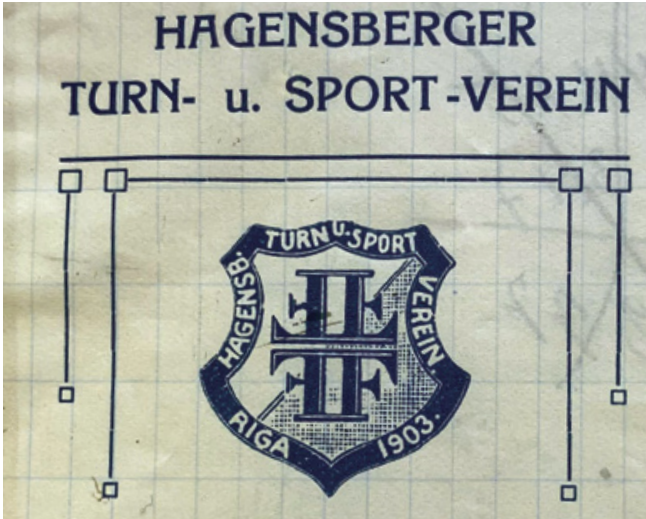

TURNHALLE UND VEREINSLOKHL: BALDOHNSCHE STR. № 11. :: TEL. 23-45, 
The motto of the $\bar{A} G S S$ and its sports greeting was «Good luck!» («Gut Heil!»). The Society's logo, like the RGS, was borrowed from the official symbolism of the German gymnastics festival with a twist of four «F» letters, expressing a desire to join and be with this modern and numerically impressive gymnastics movement.

Letter «F» is the first letter of four words in German - frisch, fromm, fröhlich, frei (lively, pious, joyful, free). These four words were combined into a motto of gymnastics by a German teacher, one of the founders of modern sports gymnastics Friedrich Ludwig Jahn (1778-1852). The colours of the Society were white and blue. Later, in the 1930s, a gold colour was added to the badge [8; p. 18]. The $\bar{A} G S S$ was headed by Dr. Oskar Suck (1864-1934) and the Gymnastics Section - by Johann Jeannot Stahl (1874?-after 1937).



Figure 2. Sketch of the badge of the $\bar{A} G S S$ (1933).

On 30 May 1904, the $\bar{A} G S S$ together with the RGS organized the first official gymnastics competition at the gym of the Riga City Real School (next to the impressive RGS building) according to the regulations of the German gymnastics societies. The competition programme, in addition to the «classical» gymnastics - exercises on the gear (gymnastics pentathlon), also included dumbbell lifting, high jump and pole vault [9].

Ägenskalns Rifle Society was formed when the Shooting Section separated from the $\bar{A} G S S$. Its Statutes were approved on 3 September 1907 [10]. The Society was formed out of fear of the Baltic-Germans for their security and property, as the time after Russia's loss in the war with Japan in 1905 and the subsequent revolution of 1905 was rather turbulent, which created the need for organization and self-defence. The building at 15 Baložu Street became the meeting place, while a field at 62 and 64 Ventspils Street was chosen as a range for shooting classes and competitions [3; p. 273].

The grand gymnastics festival in Germany became the source of inspiration for organising competitions. The festivals had been organized since 1860, the representatives of Riga and Kuldiga gymnastics societies participated in the festivals as guests in 1903, 1908 
and 1913. The visits to the gymnastics festivals were widely covered in the Baltic-German press, the leaders of the gymnastics industry and the festival guests delivered lectures at the public events of the societies.

In 1910 , the $\bar{A} G S S$ football team was established to become one of the best teams in Riga. It participated in the Riga Football League, as well as in the Riga Cup and the Cup of Gustav Adolph Agthe (1850-1906), a graduate of Riga Polytechnicum.

In 1912 , the $\bar{A} G S S$ was among 18 Baltic-German sports societies in the Baltic provinces, its athletes participated in the 5 th Stockholm Olympics as part of the team of the Tsarist Russia._A member of the Olympics team Haralds Blaus (1885-1945), a student of the Department of Architecture of RPI, won the bronze medal in shooting. These were the first Olympic Games where the athletes coming from the current territory of Latvia participated. H. Blaus was the first Olympic medallist, a representative of many sports societies and a sport official from 1907 to 1938. During the Interwar period, he was the Latvian champion and Latvian record holder in clay target shooting (1926-1938) and actively participated in sports life: as a figure skater he represented the 1st Riga Cycling Society, where he also headed the Tennis Section and participated in the Sports Committee; worked in the Latvian Proper Hunting and Shooting Society and the Latvian Hunting Society. In the history of sports, H. Blaus is also known as an outstanding first figure skater - a master of the Baltic provinces (1912) and a master of sports in Latvia (1926, 1928, and 1929). Along with H. Blaus, other participants of the 1912 Olympic Games also started doing the shooting sport at the Agenskalns Rifle Society. These were RPI students Boris von Pertel (1888-1955), Paul Lieth (1883-1950) and Lev Sytin (1891-1973), as well as Valters Bodnieks (1885 - unknown after his repatriation to Germany) and the $\bar{A} G S S$ representative - track and field athlete, decathlete Alfred Alsleben (1891-1930).

The Ägenskalns Rifle Society also leased several hectares of land with mountainous terrain in the Ägenskalns pine forest from the city municipality for a small rent. According to Herbert Oscar Alsleben (1904-1995), the environmental plan was sketched by the City Architect. In addition to the arranged fields for shooting and trap-shooting, a toboggan run, an ice rink, a tennis court, a small music stage in the form of a shell and several farm buildings were built [4; p. 62]. Later on, the $\bar{A}$ genskalns Rifle Society became a cooperation partner of the $\bar{A} G S S$.

Before World War I, on 10 February 1913, the Society celebrated its 10th anniversary with gymnastics demonstrations, a festive feast, and a ball [11].

During the first 10 years of the Society's existence, at different times it included Cycling, Motorsport, Shooting Sports and Football sections, 
the members also played tennis and developed a tourism sector. RPI students and graduates also took part in the popular sports events.

Following the recommendation of the Baltic Olympic Committee and the approval of the Russian Olympic Committee, the $\bar{A} G S S$ was entrusted with the organization of the 2nd Russian Olympic Gymnastics Competition in Riga in July 1914. This tradition continued throughout the first two Latvian General Sports Festivals $(1920,1921)$ [12].

During World War I, a military hospital was located in the bright premises of the $\bar{A} G S S$ building. The beautiful forest of Ägenskalns became a military training zone for the Russian army: with the cut trees, ditches and pits created by hand grenades. At the end of the war, the Society's building was destroyed: there were no windows and doors, equipment (gymnastic gear) and other resources were looted, and the society's flag, consecrated in 1912, was destroyed [4; p. 57]. During World War I due to the damage it caused, sports life in Ägenskalns was interrupted for several years.

\section{Activities of the Society from 1921 to 1939}

After World War I and the proclamation of the Republic of Latvia, Baltic-German organizations, including sports societies, resumed their activities and developed a sports culture in the new conditions. In the 1920s, the forms of co-operation between the Baltic-German organizations of Pärdaugava changed, with societies merging and consolidating resources.

The Baltic-German Society had to make an important decision: whether or not to re-establish the largest sports association in Pārdaugava - the $\bar{A} G S S$. Although the largest part of the gymnastics hall was restored at the end of 1921 with the selfless work of craftsmen [4; p. 58], the Society officially resumed its activities later than others the statutes of the $\bar{A} G S S$ were re-registered only on 30 January 1924 [7; p. 40]. In 1929, the revised Statutes were re-registered [7; pp. 45-48].

During the interwar period, the traditional sports - gymnastics, cycling, football, tennis, tourism, athletics, equestrian and shooting sports and motorsports - were supplemented by bandy (1922), rowing (1933) [13], sports games - basketball, volleyball (regular group tournaments for ladies, gentlemen, girls and boys took place in the mid-1920s) and handball. Under the auspices of the Society, there were 12 different sports sections: Gymnastics (56 participants); Cycling (70); Bowling (17); Motorsports (22); Table tennis (40); Shooting (44); Water sports (41); Handball (42); Tennis (58); Equestrian sports (8); Athletics (15); Skiing (41) [14; pp. 2-3]. The Society promoted the development of 
both winter and summer sports, establishing a comprehensive resource base. For example, the bendy team trained on the rink near the $\bar{A} G S S$ building.

On 24 October 1923, the new Statutes of the ĀGSS partner Ägenskalns Rifle Society - were registered [15], and it resumed its activities [16; p. 5].

At the end of 1926, the Ägenskalns Slide Society announced the liquidation of the Society and joined the $\bar{A} G S S$ [17], but the liquidation was not completed until 1931. The toboggan run in Ägenskalns pines, at the corner of Švarcmuižas and Kristapa Streets, which was taken over and successfully developed by the Ägenskalns Rifle Society in 1910, experienced a decline in the mid-1920s.

However, the Slide Society failed to arrange and maintain the tracks. Lovers of sleigh sports complained in the press that Ägenskalns was left without winter sports [18]. The merger with the $\bar{A} G S S$ opened opportunities to facilitate the development of winter sports - bobsleigh, skeleton, and sleigh sports - which the Baltic-Germans still considered their priority. However, these kinds of sports did not gain popularity in the Latvian society due to the lack of relevant tradition and high cost. At the end of 1927, the $\bar{A} G S S$ became a member of the Latvian Winter Sports Union [19].

Figure 3. Ladies on Āgenskalns slide (1934).

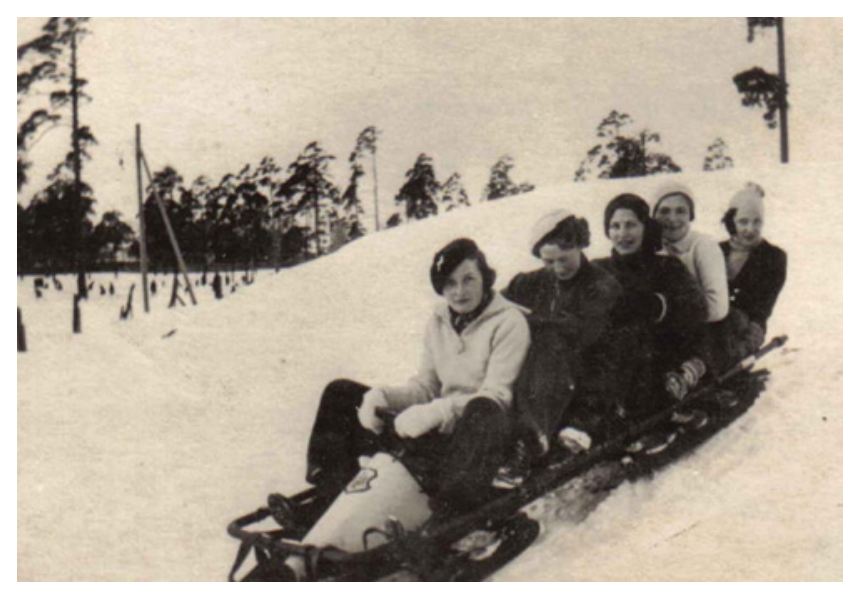

From 19 to 26 February 1928, during the week of Physical Education and Sports Propaganda, the tracks of the Ägenskalns Iceberg were selected for one of the events - demonstrations of various kinds of luge sport [20].

In 1929, the $\bar{A} G S S$ together with the Latvian Motorcyclists Society, the Kurzeme Motorcyclists Society and the Riga Motorsports Club founded 
the Latvian Motorsports Union [21]. 32 motorcycles and seven cars were registered at the Motorsports Section of the Society [4; p. 60].

At the end of the 1920s, the $\bar{A} G S S$ also joined the Latvian Table Tennis Union and in November 1936 became a member of the Latvian Basketball Union [22].

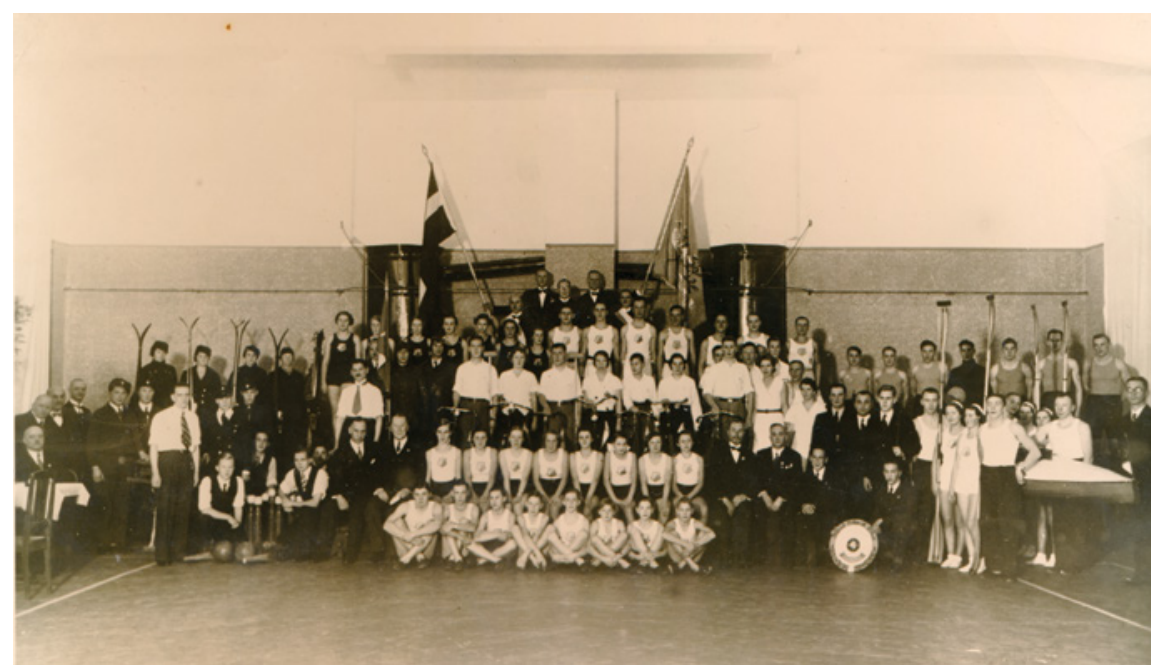

Figure 4. Traditional event of $\bar{A} G S S$ at the end of the sports season in the autumn of 1937.

The international contacts of the $\bar{A} G S S$ were primarily related to the traditional German gymnastics and sports festival. The $\bar{A} G S S$ athletes, together with other Baltic-German gymnasts, took part in the festivals in Munich (1923), Cologne (1928), Stuttgart (1933) and Wroclaw (1938). The most successful were A. Alsleben, who was among the awardwinning athletes in gymnastics and heptathlon at the 13th German Gymnastics Festival in Munich and the 14th Festival in Cologne.

In 1934, the $\bar{A} G S S$ participated in the Latvian General National Sports Festival in Riga, at the Riga City Stadium. From 1920 to 1939, the people of Āgenskalns participated in the General Latvian Sports Festival (Latvian Olympics), as well as in the national cycling festival - Unity Rides (1936-1939).

The decision taken at the general meeting of the $\bar{A} G S S$ on 30 April 1938 to merge with the Ägenskalns Rifle Society, which had no real estate, became the last step in the consolidation of the Ägenskalns BalticGerman sports societies [23]. 11 shooting sports enthusiasts joined other sports sections under the auspices of the $\bar{A} G S S$ [15; p. 12]. The long merging process was over. The value of the Society's real estate had increased to 220000 lats [25]. 
On 5 February 1938, the $\bar{A} G S S$ celebrated its 35th anniversary. From 1934 to 1939, the Society was led by the engineer Swen Heinrich Fedor von Schnakenburg (1876-1945).

There were 340 persons working in the association [14; pp. 2-3]. The annual membership fee for adults was 8 lats, for young people under 18 6 lats [15; p. 11].

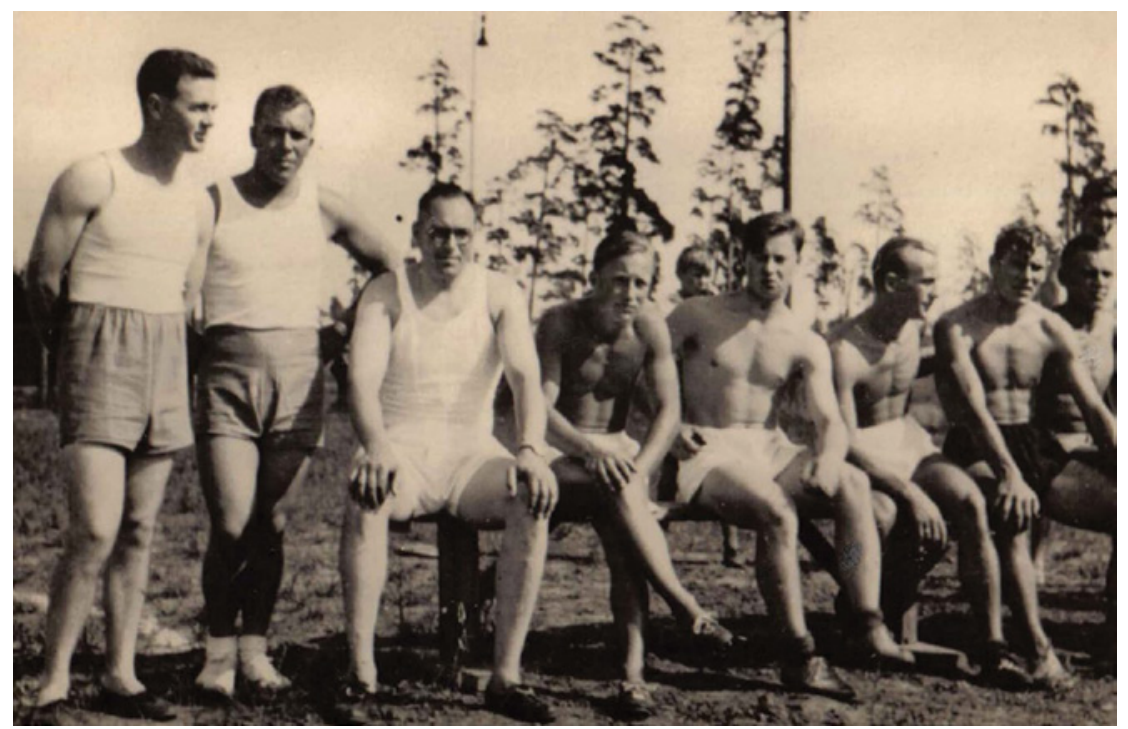

Figure 5. $\bar{A} G S S$ athletes (1938). Third from left: H. O. Alsleben.

Article 8 of the Statutes registered in 1938 included a provision stating that the Society had the right to organise gymnastics and sports classes for boys and girls under the age of 16 who could not officially become members of the organization [15; p. 27]. The members of the Society also conducted sports lessons before World War I.

School pupils regularly joined the gymnastics club. Pupils of the 6th and 7th German primary schools in Riga participated in the gymnastics festival performances [8; pp. 32, 33].

With the establishment of the Water Sports Section, rowing sport began to develop. 24 rowing boats in white-blue colour, including two racing boats that belonged to the Gymnastics Society were anchored in the territory of the First Baltic Swimming Society on the left bank of the Daugava, where the $\bar{A} G S S$ had built its own closed boat shed [4; p. 65]. By mutual agreement, the swimmers used the $\bar{A} G S S$ gym in winter [4; p. 60].

Every year the members of all sports sections attended the so-called Great Meeting (Grosses Treffen) by the water. The traveling silver cup in rowing for two was the second biggest water sports event, it was the 
master race or «Gymkhana», where the athletes competed in dexterity and speed, overcoming various obstacles.

At the end of the summer season - in October - the Society's athletes gathered for the big Autumn Festival that included a series of performances, award ceremonies, music chapel concerts, performances by actors and magicians, sessions by cartoonists and portrait silhouette painters, and other fun activities.

In 1939, in accordance with the Law on Non-Profit Societies and their Unions and the Agreement on the Transfer of Latvian Citizens of German Nationality to Germany [25], 19 Baltic-German sports societies ceased their operations [26]. On 4 November 1939, all Baltic-German sports societies, including the $\bar{A} G S S$ [27], were closed [28].

At the beginning of the liquidation process of the Baltic-German sports societies, the liquidators were appointed. Alberts Rumba (1892-1962), Secretary General of the Latvian Committee for Physical Culture and Sports, and Fricis Eduards Upelincis (1894-1950), Head of the Housing Department of the Security Headquarters, economist by education, a graduate (1930) of the University of Latvia, who had studied chemistry at RPI, were appointed liquidators of the $\bar{A} G S S$ [14; p. 7]. Later, A. Rumba resigned from this duty, and Aleksandrs Udris (1902-1978) was appointed in his place. The President of the Society, an engineer S. H. F. von Schnakenburg, a Fellow of the Chairman, house manager H. O. Alsleben, and the Head of the Society's Tennis Section Fridrich Kreizer (1889-?) took over the responsibility for the real estate and movable property from the board of the Society [8; p. 54]. They were responsible for the values created by the Society in 36 years.

The liquidation process of the Society began on 3 September 1939 and lasted for several years, ending on 28 February 1941 with the last report of the liquidators on the termination of the process [29; p. 34.].

The building and the territory of the Society were used as a packing point for the repatriation of the former Latvian citizens of German descent before leaving Latvia [30].

On 16 November 1939, F. E. Upelincis and A. Üdris, the liquidators of the Society appointed by the Minister of Public Affairs, arrived at 7 Baldones Street to take over two pieces of real estate, which were valued at 71740.84 lats in the 1938 balance sheet [27; p. 11]. Teodors Rušinšs (1899-1967), a cassation engineer of the Mortgage Bank of Latvia and a graduate (1928) of the University of Latvia, who started his studies at RPI, in 1940 performed an appraisal of the real estate of the company in liquidation in the amount of 161127 lats [29; 22. p.].

On 20 November, the Board of the $\bar{A} G S S$ submitted an application to the liquidators of the Society, asking for permission to export some movable property included in the acts to Germany according to 
the inventory lists containing almost 900 items. The lists were later supplemented with the entries «worn», «not working», «torn», «broken», etc. Apart from the furniture - tables, chairs, sofas, cabinets, lamps, mirrors - and other listed items, all marked as worn out and therefore worthless, the list included also sports gear for volleyball, shooting, athletics, weightlifting, tennis, referees' equipment and also four bobsleighs. The Ministry of Public Affairs had no objections to exporting the goods abroad. There was very little time left for the representatives of the Society, the international situation was changing from day to day, tensions and the impending war made the civil service more nervous, and the property of the $\bar{A} G S S$ was irrevocably looted and demolished.

The Ministry of Public Affairs and the Ministry of Education wanted to take over the gym, while the Ministry of War filed documents to overtake the riding arena and horse stables to transfer them to the Sports Club of the 5th Riga Defence Regiment [31; p. 21]. Later also the gym was acquired by the Guard Club and it became known as the Guard Gym [32]. In April 1940, the Defenders' Basketball Championship was held there [33].

On 3 August 1940, all property of the $\bar{A} G S S$ was officially transferred to possession of the Latvian Army with the help of the Construction Unit of the Procurement Department of the Ministry of War [29; p. 24]. No compensation (payment) for the use of the property was provided to the Society.

According to the repatriation agreement, G. Baerent (?-?), the representative of the German Government in the society-related matters in Latvia, was entitled to sell the movable property of the Society to the Red Army, which agreed to repurchase the property [29; p. 33]. Correspondence about purchase or exporting the possessions to Germany did not lead to any meaningful results, and the number of belongings fell sharply because they were apparently misused.

The Society Unit of the People's Commissariat of Internal Affairs of the Soviet Socialist Republic of Latvia did not object that the movable and immovable property of the Society would remain at the disposal of the units of the Red Army. The Red Army asked for permission from the Society Unit to repurchase the movable property of the $\bar{A} G S S$.

The liquidation had been delayed for several months. On 9 September 1940, a Report was written asking for action because «1) liquidation has been dragging on for several months; 2) the property to be liquidated has had to be handed over and taken over several times by different users, which complicates the liquidation process and multiplies expenses; 3 ) the real estate and movable property belonging to the liquidated society is custom built, purchased and suitable for various sports and the total value of the property is about 16500 lats; 
liquidators ask the Commissariat of Internal Affairs to urgently decide on the issue of the final allocation of real and movable property belonging to the Ägenskalns Gymnastics and Sports Society to an organization for the promotion of the physical culture» (author's note, underlined in red pencil in the original) [27; p. 44].

On 9 September 1940, the troops of the Latvian Army left the premises and territory of the building at 7 Baldones Street. A property security guard Jānis Tropiñ (?-?) was hired, who worked for five lats a day. On 21 September, the Society's property was taken over by the Red Army, which did not repurchase it.

The windows in the rooms of the gym were broken, central heating devices were damaged, a part of the fence along Baldones Street was torn off.

The Society had an unsettled loan amounting to 7461.88 lats at the Mortgage Bank of Latvia [29; p. 27]. In October 1940, the Mortgage Bank of Latvia was transformed into the Communal Bank, and the $\bar{A} G S S$ had to repay the debt it had at its old bank, now in the form of the new «combined - restructured loan» in the amount of 3300 lats at $5.5 \%$ within 28 years, starting from 1 November 1940 [ 29; p. 31].

At the end of 1940, none of the Baltic-German gymnastics societies [34], including 56 members of the gymnastics section of the $\bar{A} G S S$, participated in the Latvian championship in gymnastics. On 28 February 1941, the liquidators submitted a report to the Main Apartment Board of the Utilities Commissariat stating that «the liquidation of the Āgenskalns Gymnastics and Sports Society has been terminated» [29; p. 34].

\section{Yellow Āgenskalns Building and the $\bar{A} G S S$}

In the second half of the 19th century, Baltic-German and Latvian architects in the provinces of Kurzeme and Vidzeme participated in the design and construction of sports premises, they also got involved in the life of sports societies and participated in sports competitions.

The information about the activities of the Society and the house built in the Art Nouveau style can mainly be obtained considering the reports in the German and Latvian press and materials of the LSHA NAL, as well as the memoirs of the Baltic-Germans in various publications. The chronicle of the Alsleben Family [4] written by H. O. Alsleben, a member of the $\bar{A} G S S$ and one of its leaders, is of particular interest. The chronicle not only provides insights into socio-political events and the economic changes, but also discusses their impact on the cultural and sports processes over several centuries. 
From 1903 to 1910 , the $\bar{A} G S S$ did not have a place of permanent residence or its own property. In the first years of its existence, its temporary residence was located in Ägenskalns Park, in G. J. Ebert's house mentioned above. Events with public gymnastics demonstrations took place in several locations - in the park, on the stage of the Summer Theatre or in the premises of the Ägenskalns Sociable Society building at 15 Baložu Street, a temporary gym at 17 Slokas Street was also used [35]. After the reconstruction of the gym on Baložu Street and the establishment of the Ägenskalns Rifle Society in 1907, the premises of the building were rented by shooting sports enthusiasts.
Figure 6. Situation plan of the land plot acquired by the $\bar{A} G S S$ at 7 Baldones Street (1910).



The information about the architectural design and construction of the building may be obtained analysing the sketches and plans developed by architects Leopold Riemer (1880-1923?) and H. Blaus, a graduate of the Department of Architecture of RPI, as well as Alfrēds Laukirbe (1901-1993), a graduate of the Faculty of Architecture of the University of Latvia. The photo materials about the exterior of the building and the interior of the premises, which could give a convincing 
picture of the building and its reconstruction from 1910 to 1940, are scarce. Until now, only a few photographs have been preserved, they are stored in the materials of the Department of Press and Societies of the Ministry of Public Affairs [36; p. 1] and are presented in the abovementioned chronicle of the Alsleben Family.

At the beginning of the 20th century, G. J. Ebert's house became too narrow and small for a large number of people who wanted to exercise [4; p. 56], and the Construction Committee of the Society started considering the issue of building its own house. An engineer Raimund Kowarzyk (1882 - after 1957, in Germany) was the Head of the Committee, he obtained a university degree in Munich, Germany. This position was entrusted to him at the general meeting of the $\bar{A} G S S$ on 24 January 1909 by the first president of the Society O. Suck. The aim of the Committee was to address the issue of building a house. Initially, the plots of land on Daugavgrivvas and Ägenskalna Streets were considered, but these places lacked perspective for further development of sports [24].

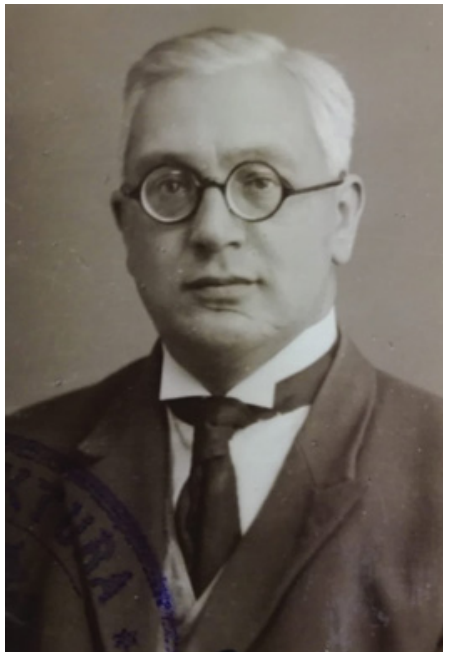

Figure 7. Chairman of the $\bar{A} G S S$ (1909-1926), engineer R. Kowarzyk (c. 1930).

On 13 February 1910, the general meeting of the Society took place in the hall of Ägenskalns Park House. At this meeting, the Construction Committee accepted a report with a proposal to buy a plot of land on the corner of Baldones and Švarcmuižas Streets, which was located in the 2nd Jelgava Suburb of Riga. A plot of land of 253 dessiatines or 1155 square meters was purchased for 1211 tsarist roubles. The property was valued at 2800 tsarist roubles. The Society undertook a commitment to build a house with a gym within two years. Engineers Emil Barthels (?-?) and R. Kowarzyk were authorized to enter into a purchase agreement with 
a Riga merchant and a baker Otto Grīnbergs (1870 - after emigrating to Germany in 1939) [7; p. 11]. O. Grinbergs was the sub-owner of the real estate of the society that later became the $\bar{A} G S S$, while Johann Cristoph Schwartz (1846-1915), a professor, lawyer, Riga Councillor, and President of the Orphans' Court, who at that time lived in Halle an der Saale, Germany, was the master owner of the building. The President of the RGS, an Honorary Member of the $\bar{A} G S S$, Conrad Bornhaupt (18411914) was his legal representative in the property transactions [7; p. 13].

The owner of Švarcmuiža sold the plot of land under the following conditions: 1) to pay the annual land tax of 20 rubles one year in advance; 2) not to establish hotels or trade outlets and not to engage in the sale of beverages; 3) not to divide the property without the direct consent of the land owner. The contract of sale was signed on 13 April 1910 [7; p. 11]. On 19 April 1910, the foundation stone of the new Society building was solemnly laid [37].

The author of the sketches and the layout of the two-storey Art Nouveau building was the architect of Riga, a graduate (1906) of the Department of Architecture of RPI L. Riemer. He had worked as a drawing teacher at Kuldiga Gymnasium (1906-1907) and was an architect of this city (1907-1908), later he worked as a mathematics teacher at Tomsk Business School in Russia (1908-1909), and from 1909, he was the architect of the city of Riga [38].

Art Nouveau, the dominating architectural and design style of that time, which emerged at the end of the 19th century and existed until World War I, also influenced the choice of graphic ornaments and letters with the features of new style used in the design of the sports competition programmes.

Figure 8.

The sketches of the facade with the main entrance to the $\bar{A} G S S$ building (Baldones street) and Āgenskalna street facade by architect L. Riemer (1910).
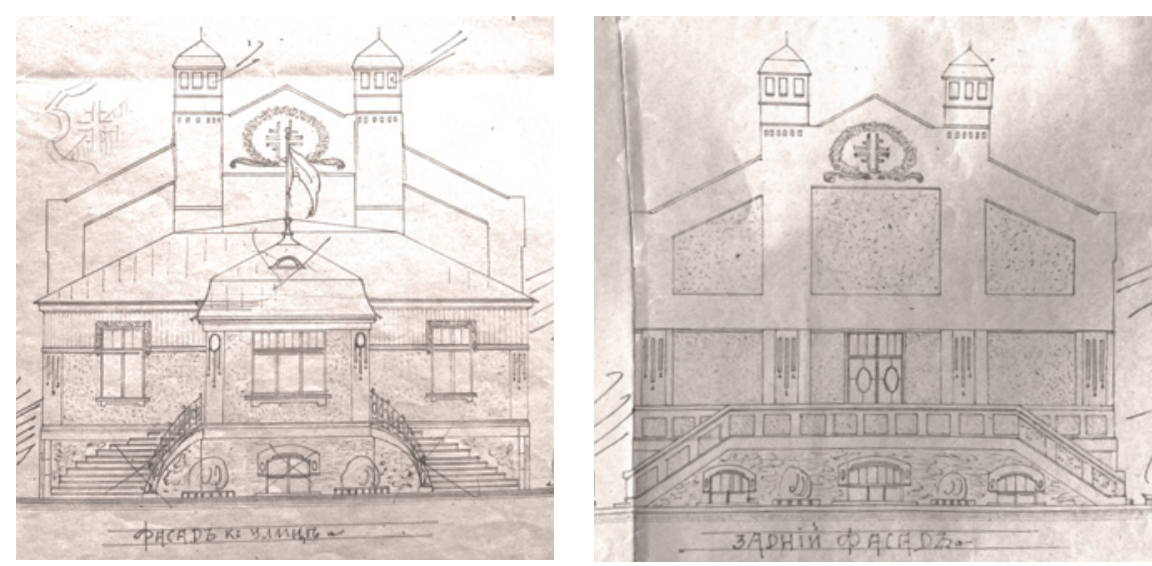


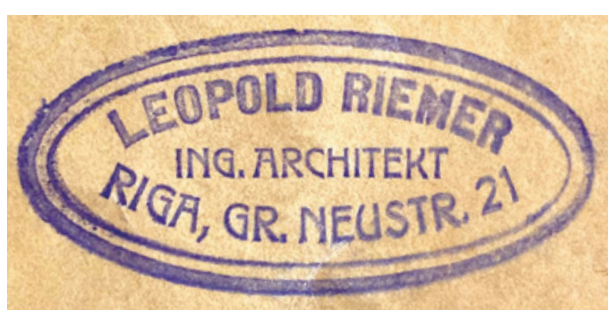

Figure 9. Stamp of L. Riemer on the engineering design of the $\bar{A} G S S$ building developed in 1910 .

The Construction Supervision Committee of the Administration of Vidzeme Province approved L. Riemer's design on 12 June 1910 [39]. According to the sketches of the architect's design, it was intended to decorate the gable of the building with a relief tab - the coat of arms of the $\bar{A} G S S$ - a stylized entwinement of four letters «F» surrounded by a wreath. Later, the coat of arms of the society was preserved and was included in the escutcheon in the 1935 reconstruction sketches of the building by architect $A$. Laukirbe [39]. The coat of arms adorned the building until the liquidation of the Society in 1940. It was also used as the logo in the official document templates of the Society.

The property at 11 Baldones Street (at present - 7) stretched until the forest of $\breve{S}$ varcmuiža and one of its edges bordered with the current Villipa Street. The main facade with the entrance stretched along Baldones Street. Originally, the property also included a sports field, a tennis court and a house with a gym [40; p. 3].

From the main entrance on Baldones Street, a semicircle staircase led to the ground floor lobby, which could be entered both from the right and from the left. On the ground floor there was a wardrobe, a gym, a room for gym gear, which could be converted and used as a stage, a changing room, a hall for board meetings and public events, and a toilet. There was an exit from the gym to the terrace, which opened a view to the sports field and the Švarcmuiža Forest. In the basement, there was a skittlealley (bowling), billiard hall, dining room, kitchen and warehouses [39; p. 56].

On 14 November 1910, the consecration and official opening of the $\bar{A} G S S$ building took place. It was attended by 260 guests from various public organizations and German sports societies [41]. Riga got the second largest gym after RGS hall. The Taxation Committee of the Second Riga Insurance Society assessed the building at 30700 tsarist rubles, the value of the land - at 1535 rubles [40; p. 9].

The impressive Art Nouveau stone building located near the old Zasumuiža surrounded by forests dominated over the whole area, and the people of Āgenskalns called it the Big Yellow Building (Gelbe Buda). It was the most impressive public building in Ägenskalns, which was used for organising not only sports events, but also social events for 
the local residents of different age: there were celebrations of religious holidays and Walpurgis Nights, family soirees, children festivals, spring and autumn festivals, symphonic music concerts, educational events, carnivals, and masquerade balls.

\section{Modernization of the Building on Baldones Street and its After-Life}

Due to the damage caused by World War I, which was followed by the Latvian War of Independence, the natural development of the cultural and sports life of Ägenskalns and its surroundings was suspended for many years. Thus, the $\bar{A} G S S$ wanted to expand its operations, as well as modernize its building on Baldones Street. On 12 April 1927, the Central Land Management Committee granted the land to the $\bar{A} G S S$ [42]. The expansion of the land plot also continued in 1929. The decisions of the Committee created favourable environment for the development of the Society's infrastructure. Therefore, its goal - to expand activities in the field of sports and culture - could be reached.

On 22 September 1927, at the meeting of the Committee of Riga Construction Board, the construction project of the roof floor of the $\bar{A} G S S$ building at 11 Baldones Street, developed by architect $H$. Blaus, was approved. The purpose of the reconstruction was to build apartments for the Society's house manager and economist [4; p. 56]. On 17 November, the works were completed and accepted [39; p. 11]. On 12 February 1928 , the 25th anniversary of the Society was widely celebrated in the building with the consecration of a new flag [12].

Figure 10. The engineering design for the construction of the roof floor of the building at 11 Baldones Street by architect H. Blaus (1927).

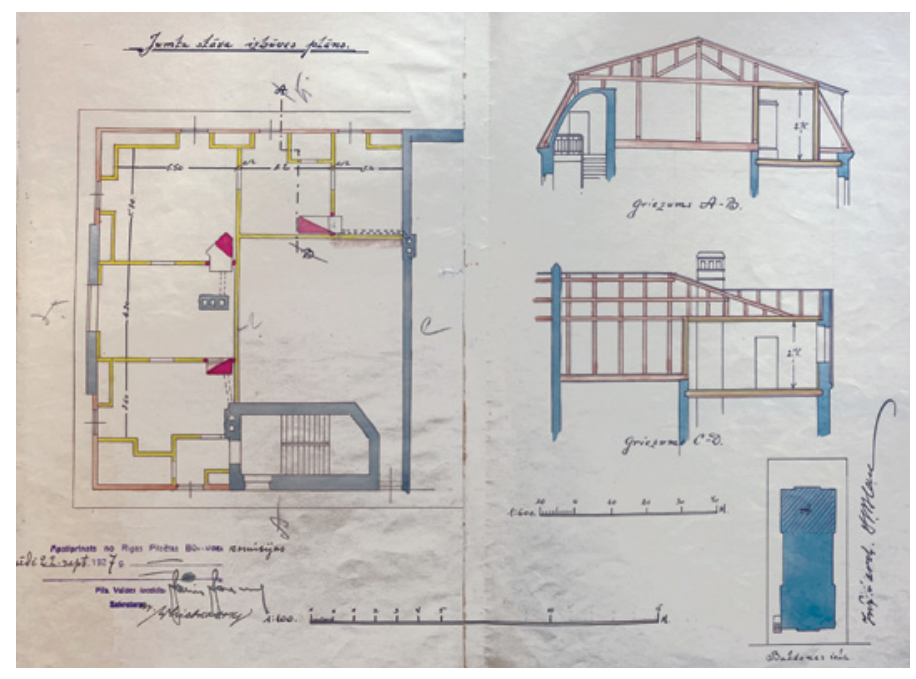


The activities and role of the Society in the sports and social life of the neighbourhood expanded rapidly in the 1930s. Development required a more modern, up-to-date infrastructure.

In the mid-1930s, the Society gained financial and economic stability: a mortgage of 25000 tsarist rubles was repaid (1930) [7; p. 30.]; it expanded the real estate by merging two plots of land No. 156 and No. 157, increasing the total area to 3315 square meters (1934) [7; p. 57]. On 4 June 1934, the property rights were secured by the $\bar{A} G S S$. The purchase price was 4010 lats [36; p. 3]. On 24 October 1936, a purchase agreement was approved for a new plot of land at 23 Ägenskalna Street, which was bordering the existing plot of land of the Society. The new plot of land was purchased for 22086.08 lats. Wooden arenas and horse stables were built on the new plot. This provided an opportunity to develop the sports life of the Society in a more comprehensive way, for example, to develop equestrian sports [36; p. 5].

As the $\bar{A} G S S$ became more prosperous, it became possible to consider the improvement of the building, including the expansion of the gym and arrangement of a shooting range. In 1930, a permit was obtained for the construction of a shooting range on the floor of a vaulted basement of the sports building, which was used only for shooting with small-calibre weapons [39; p. 13].

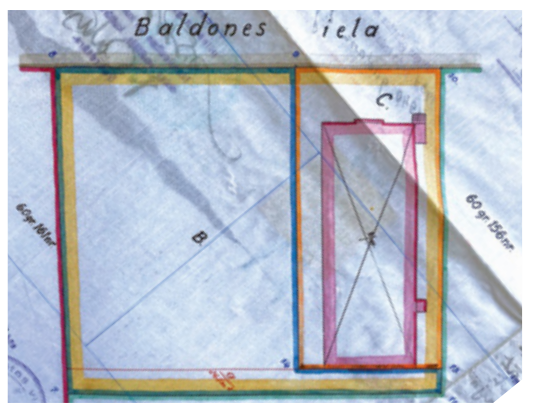

Figure 11. Situation plan of the $\bar{A} G S S$ property (1934).

On 7 November 1935, the engineering design of architect $A$. Laukirbe for the reconstruction of the first floor of a stone building at 7 Baldones Street was approved [39; p. 17]. After the reconstruction, the functions of the premises changed, the building got an open terrace facing the courtyard, three changing rooms for gymnasts, the Society' board room and a 257 square meter large gym. In the basement, there was a small hall, a buffet room, a kitchen, utility rooms and a skittle-alley [39; p. 30].

In 1935, a new Swedish galvanized tin roof was installed on the building. The works also continued in 1936, when the first floor of the building was rebuilt and a two-storey house was added. The design of A. Laukirbe was approved on 9 July [39; p. 28]. 


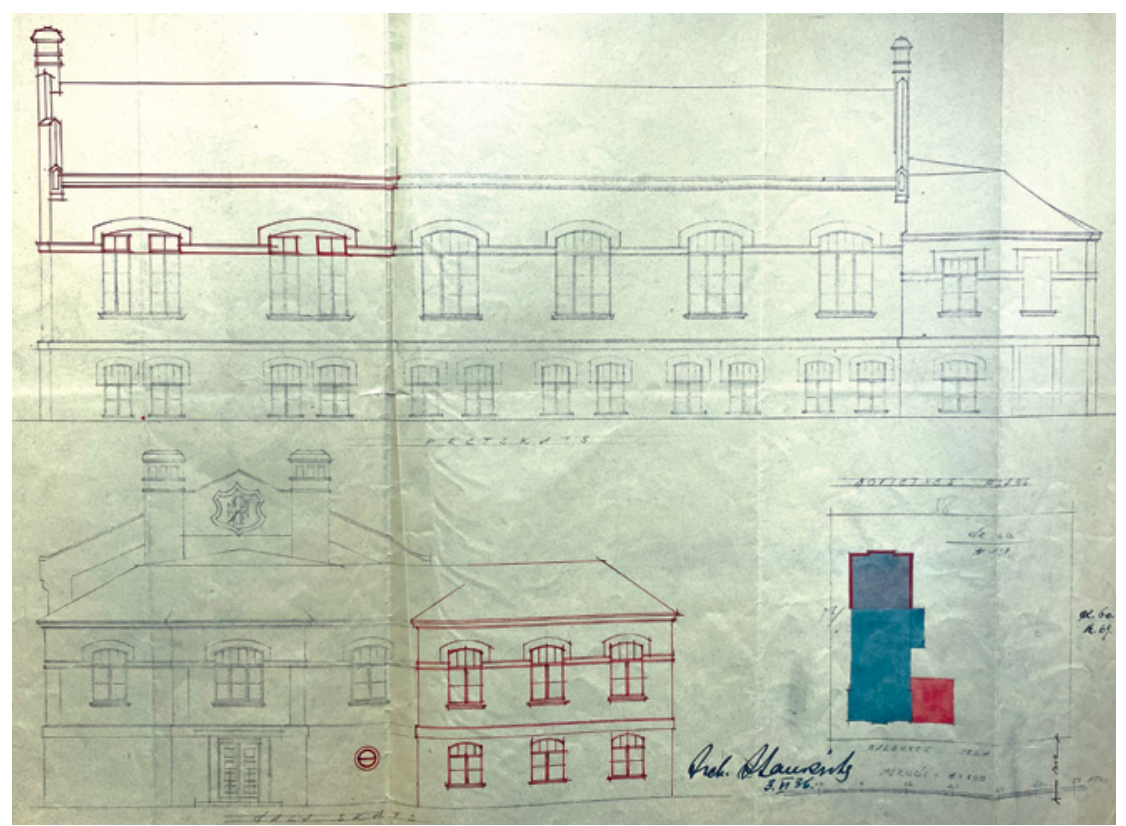

Figure 12. The engineering design for the reconstruction of the first floor of the $\bar{A} G S S$ building by architect $A$. Laukirbe (1935).

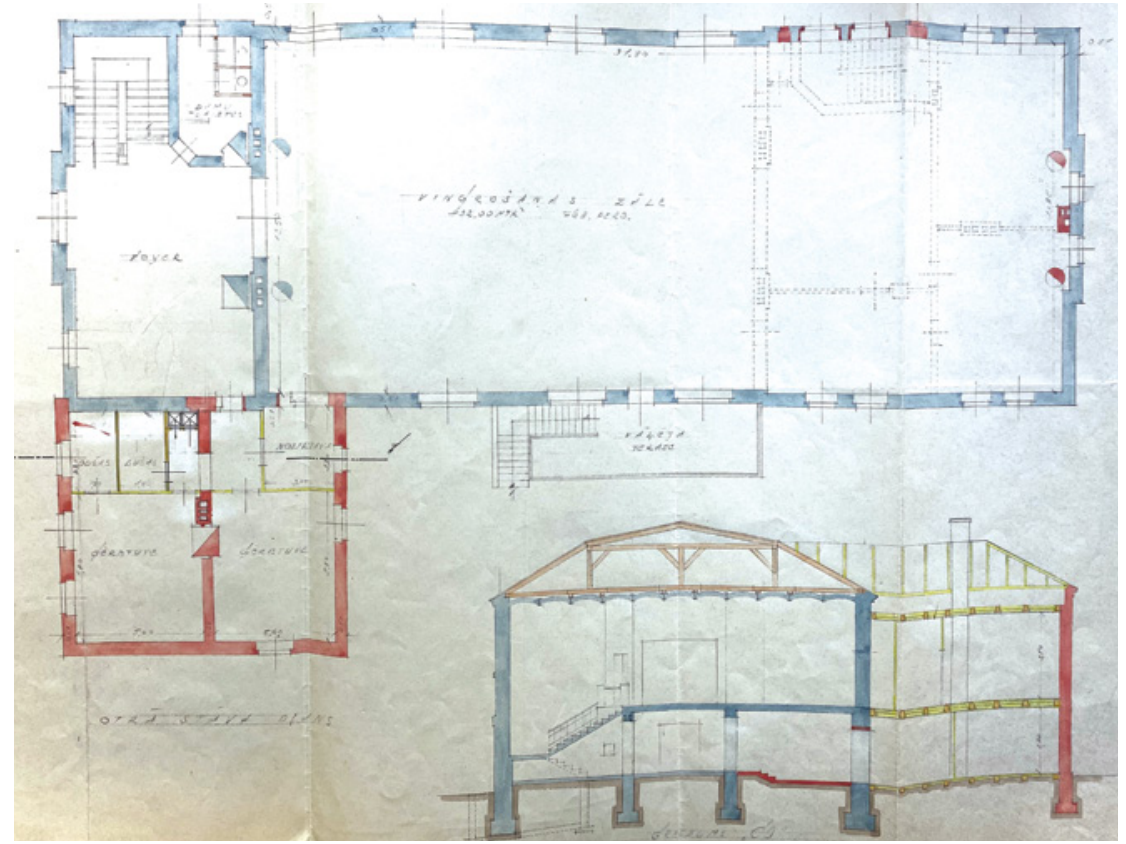

Figure 13. Plan for the reconstruction of the gym in the first floor and the extension of the building by architect A. Laukirbe (1936).
Activities of

Āgenskalns

Gymnastics and

Sports Society and

its Headquarters at

7 Baldones Street 
It was planned to arrange two shower rooms, two changing rooms and a warehouse on the ground floor of the extension. However, the rebuilt 432 square meter large gym was the main gain of the renovation. The reconstruction of the gym was carried out using the support of the joint stock company «C. CH. Schmidt Rigas cementa fabrika» management. In the same year, the building was equipped with the central heating and gas, and the main facade of the building was changed. The construction project for sewerage and sewage was approved on 19 May 1937 [39; p. 34].

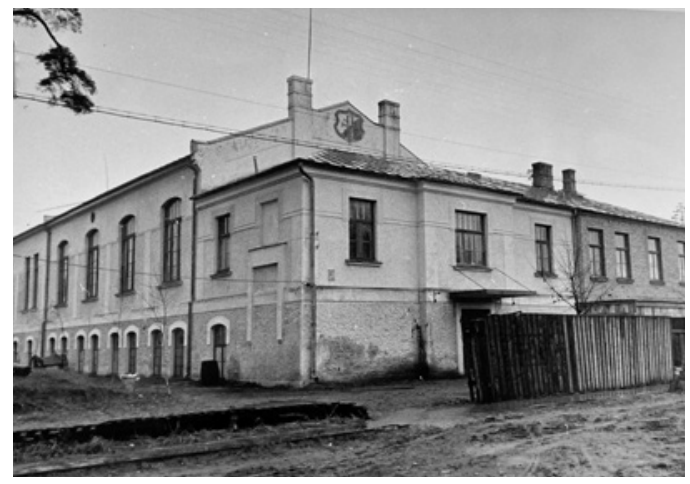

Figure 14. $\bar{A} G S S$ building with a newly built extension (1939).



Figure 15. $\bar{A} G S S$ arena for equestrian sports (1939).

The biggest winners after the reconstruction of the building were Riga tennis players. Until now, their only opportunity to practice playing in the winter season was in Bergmanis' Tennis Hall, at 1 Ganibu Embankment [43]. After the reconstruction of the building on Baldones Street, the gym was enlarged, giving up the stage and some auxiliary rooms $[4 ;$ p. 60]. The new hall fully met the requirements of the game of tennis with its wide fields behind the side and end lines. The hall was equipped so that it was possible to play basketball, volleyball and handball. On 18 October 1936, the largest tennis hall in Riga was opened with the demonstrations of tennis games.

From 31 January to 7 February 1937, the first official indoor tennis tournament was held, in which 13 tennis players played in singles and eight pairs in doubles [44]. The advantages offered by the new indoor premises also promoted closer cooperation with the 1st Riga Cycling Society, which during the interwar period also turned to the game of tennis and used the premises of the $\bar{A} G S S$.

Over the years, the reconstruction of the building had also changed the layout and functions of the premises - on the ground floor there was a skittle-alley, small hall, library, boardroom, shooting range and two 
apartments (one-room and three-room), central heating and staircase, on the first floor - a large gym with auxiliary rooms (shower, sports equipment and changing room).

In the 1930s, the $\bar{A} G S S$ grew, expanded, having become one of the richest and most influential Baltic-German sports societies not only in Riga, but also in the entire Baltics. The Society had two pieces of real estate at its disposal: a 3315 square meter plot of land with a building (41 meters long, 15 meters wide) at 7 Baldones Street and a 6062 square meter plot of land with a wooden structure (arena for equestrian sports - 40 meters long, 14 meters wide) at 23 Ägenskalna Street [36; p. 2]. The total value of these properties was 71740 lats [29; p. 1]. Sports and gymnastic gear was purchased for an amount of 14500 lats [14; p. 2]. Three open tennis courts helped promote popularity of the game during the summer months.

After World War II, the building at 7 Baldones Street was handed over to the Sports Society «Daugava». The building underwent several reconstruction and improvement stages. In 1949, a new boiler room was added to the building and the central heating, ventilation and sewerage systems were rebuilt, the load-bearing walls of the building were fixed to the foundation [45]. Outdoor training grounds for volleyball and basketball, as well as an indoor athletics hall and a shooting range were built, it was planned to purchase modern sports equipment. The plan to install a ski base and an ice rink was not implemented either, because due to the high groundwater level, the water leaked into the basement as the ice melted $[46,47]$.
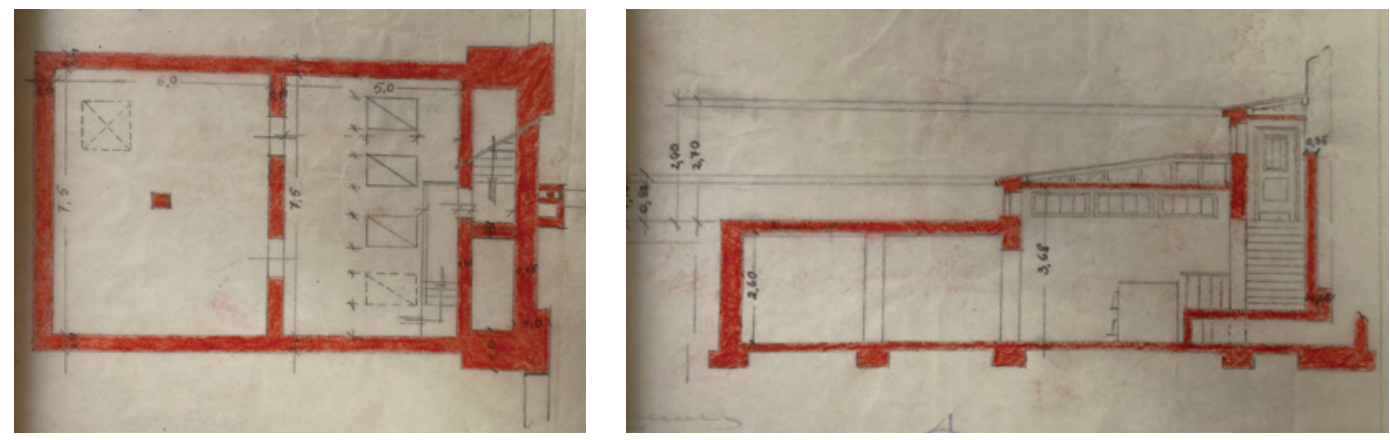

Figure 16. Plan and section of the boiler room at 7 Baldones Street (1949).

In 1951, there were only two tennis courts on the site, which was not enough for professional growth of 200 athletes [48].

In 1960, the building underwent major renovation, which lasted for almost two years $[49,50]$. At the beginning of the renovation process, the old roof of the building was dismantled and interior repairs were 
started. The interior repairs had already been completed, but the new roofing had not yet been installed. The renovated building stood without a roof for several months and was flooded. At the end of 1961, a largescale reconstruction of the building was planned, with the plans to add a gym complex. The design task envisaged that the hall could be used by 24 athletes at the same time. This project did not materialize because the overhaul of the building and the construction of the roof required significant resources [51].

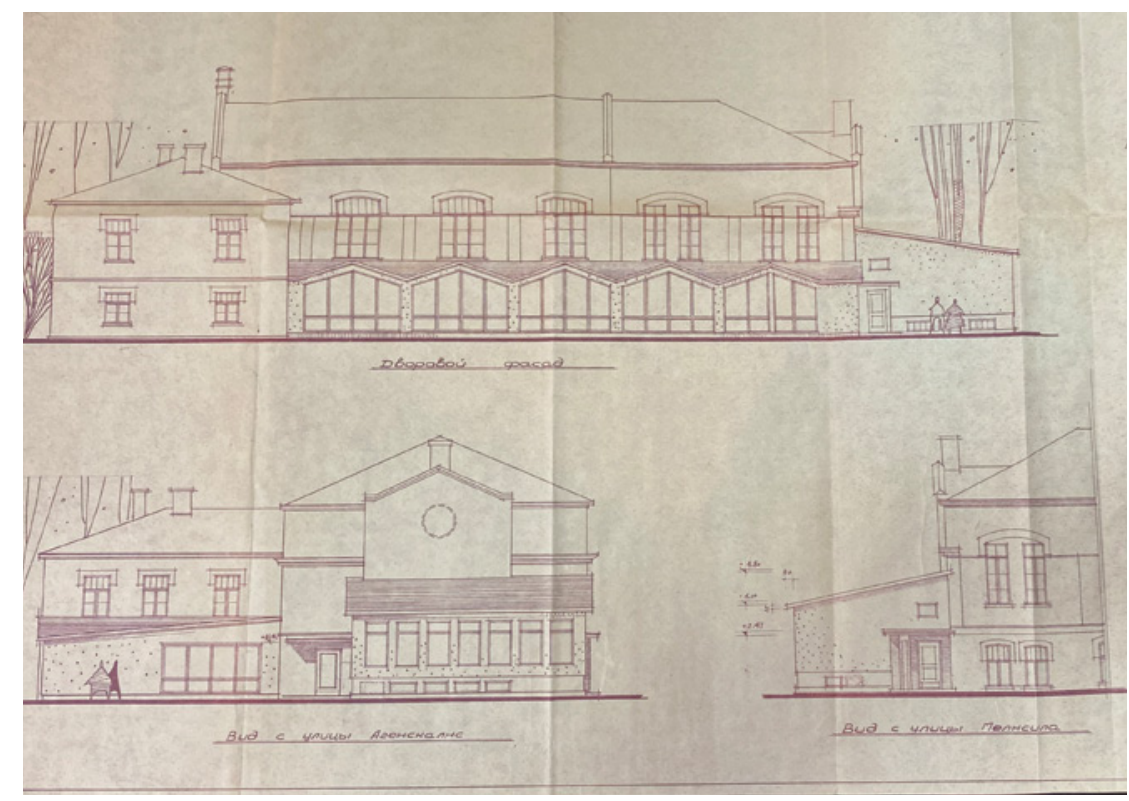

Figure 17. Design of the extension of the gym of the building at 7 Baldones Street (from the courtyard side, Ägenskalna Street and Melnsila Street) (1961).

In 1962, the central heating system of the building was improved again and the electrical installation was changed [52]. In 1964, marking the 20th anniversary of the Sports Society «Daugava», four tennis courts were renovated, three were covered with the crushed brick, one was covered with asphalt, the territory was greened, and places for spectators were arranged $[53,54]$.

At the end of the 1960s, the roof of the building was torn down during the storm, which was urgently restored by a government decision, replacing the rotten beams and raising the roof structure so that the ball could be raised higher while playing volleyball.

In 1971, another floor was built above the gym on the first floor, which housed the resource offices, a meeting room and a room for the head of the Sports Society «Daugava». Within the project, the auxiliary 
premises on the ground floor and the administration premises on the first floor of the building were re-planned, a terrace with spectator stands above the boiler room was created, and the boiler room was renovated. The large tennis hall was equipped with a balcony for spectators. Cosmetic repairs of the whole building, replacement of windows and doors, as well as utilities were scheduled. A sauna with a swimming pool was built on the ground floor, it was planned to connect a telephone line to the newly created floor [55].
Activities of

Āgenskalns

Gymnastics and

Sports Society and its Headquarters at 7 Baldones Street
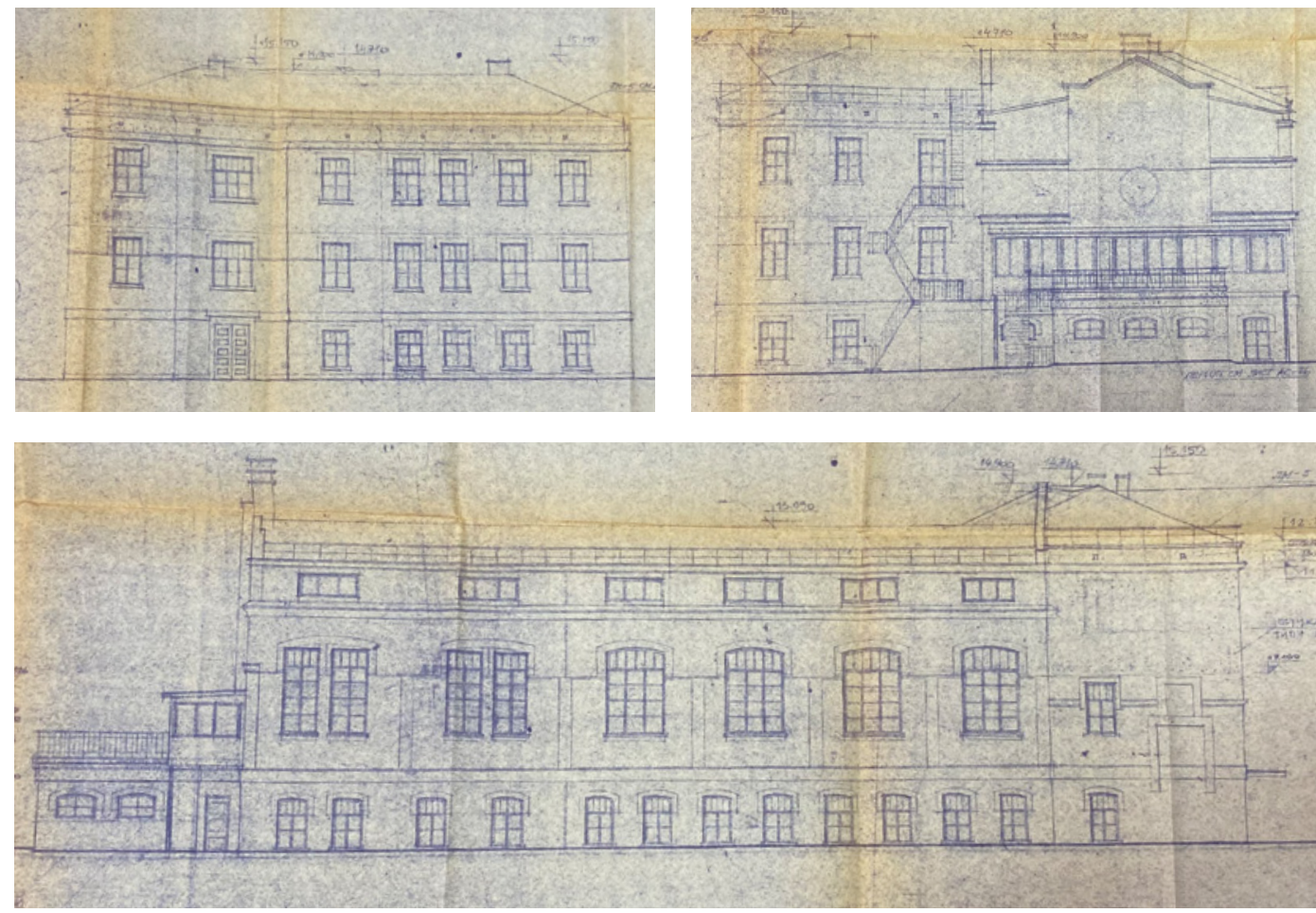

Figure 18. Facade views of the building from Baldones Street, Āgenskalna Street and Villipa Street of the Sports Society «Daugava» (1971).

Under the leadership of a civil engineer, RPI graduate (1984) Irina Šatirjonoka, the premises were re-planned in 1998, not providing for the reconstruction of the capital walls and load-bearing structures. Semibasement windows with a $15 \mathrm{~cm}$ recess were built, creating imitation windows. Warehouses (later garages) were added on the yard side [56]. 


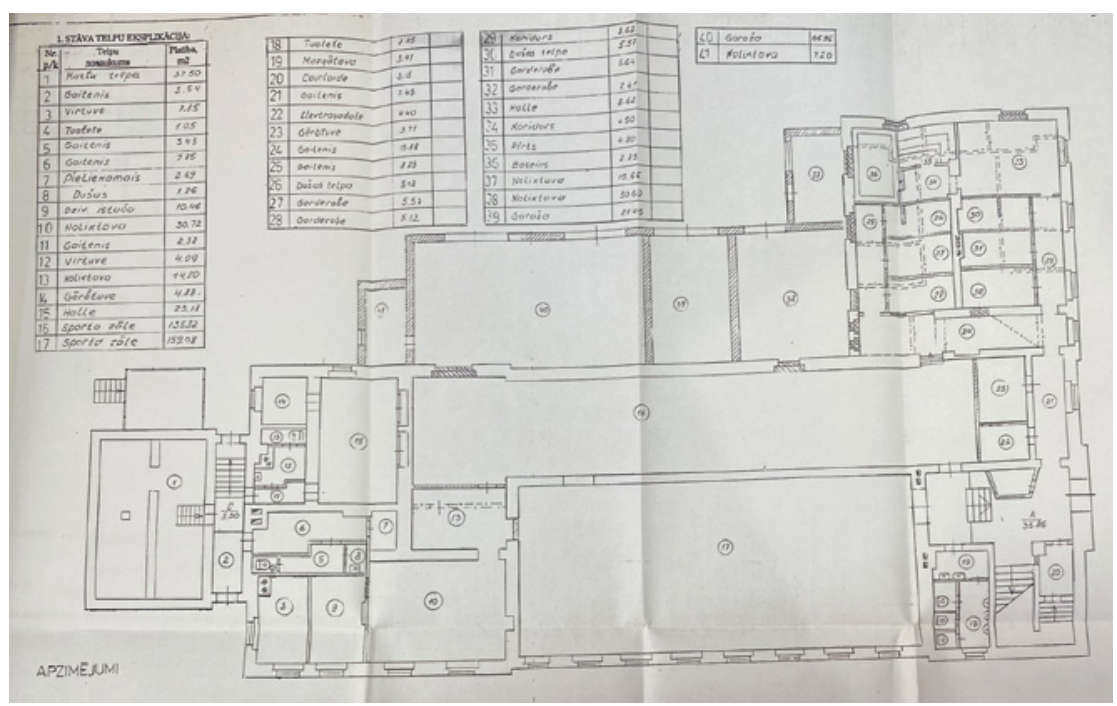

Figure 19. Floor plan of the building at 7 Baldones Street with newly built warehouses (1998).

In 2003, under the supervision of a civil engineer, RPI graduate (1977) Andrejs Ugrimovs, the building was renovated and plants were replanted in the area [57]. The building was connected to the city water supply and sewerage network. In the same year, the warehouse (garage) on the yard side of the building was demolished and an external staircase leading to the gym on the first floor was installed.
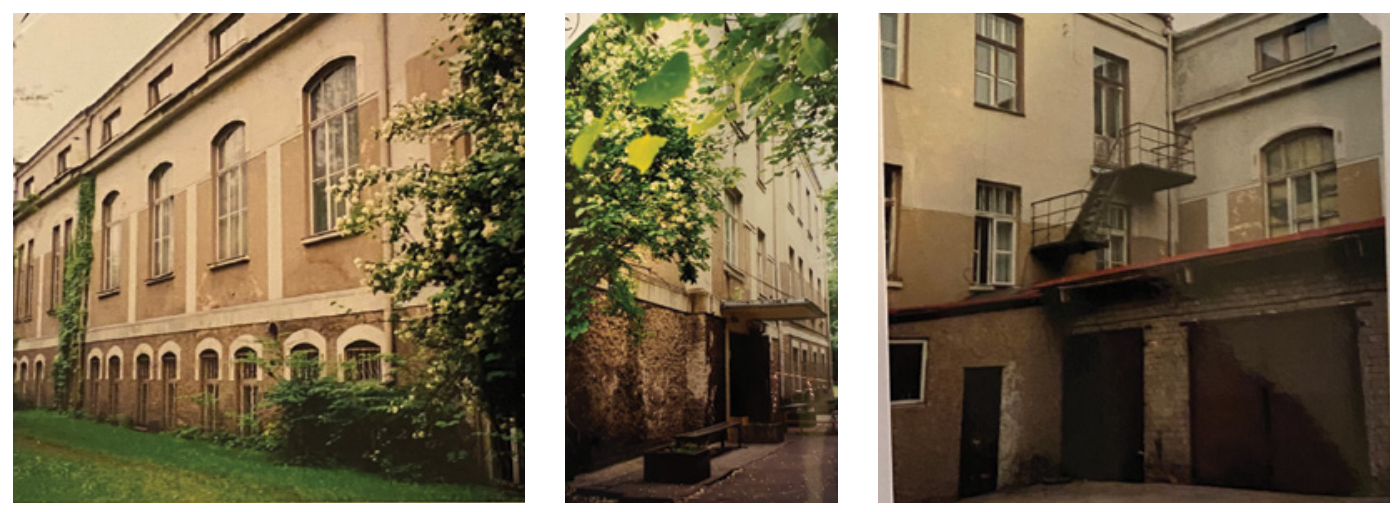

Figure 20. Photo fixations of the building at 7 Baldones Street before reconstruction: facade view from Villipa Street; facade view from Baldones Street; facade view and the warehouse from the courtyard (2003). 

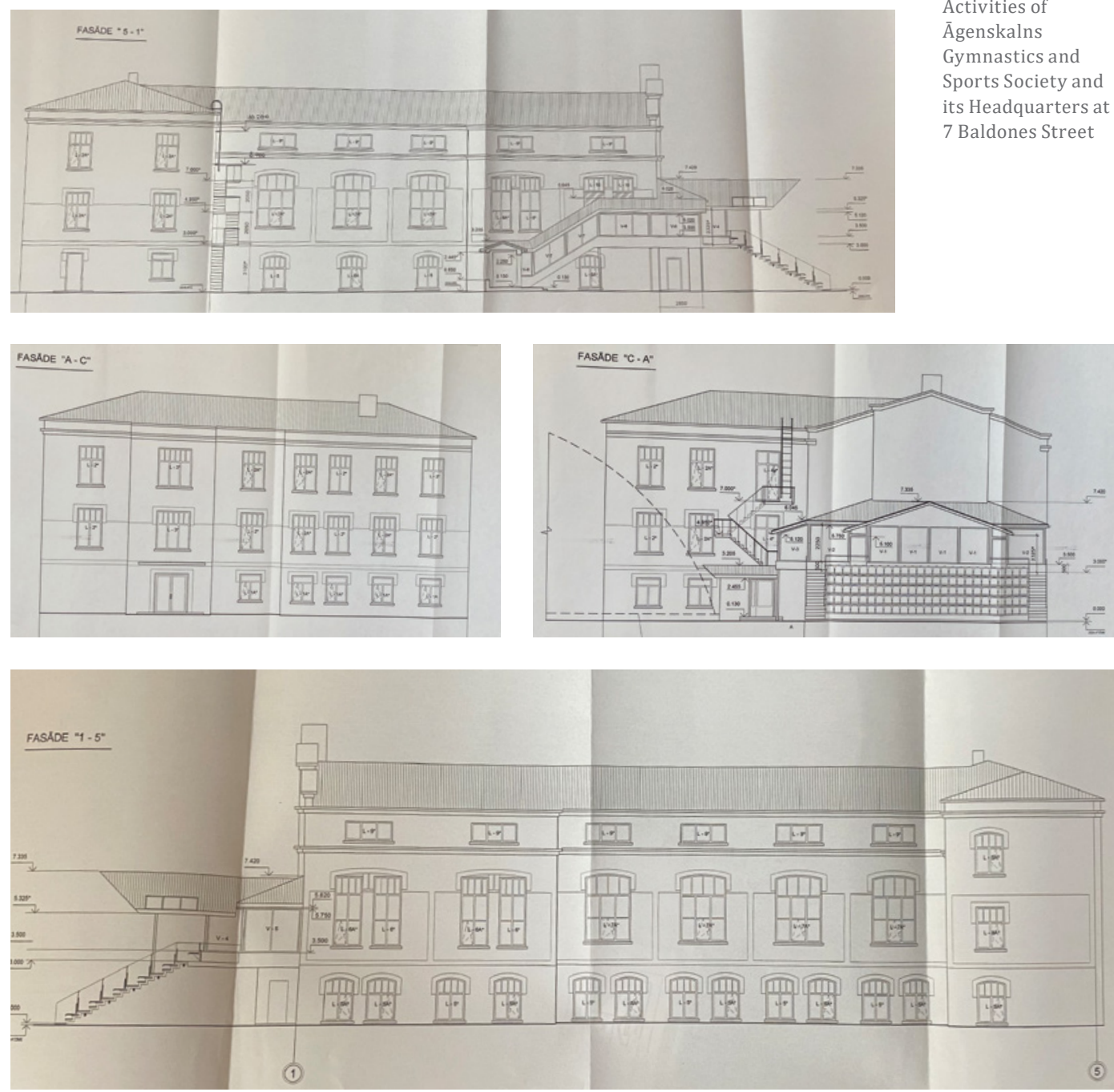

Figure 21. Facade of the building at 7 Baldones Street after changes in the project: from the courtyard; from Baldones Street; from Āgenskalna Street; from Villipa Street (2003).

In 2003, under the leadership of architects RPI graduate (1982) Igors Kirsanovs, and RPI graduate (1979) Viktors Ugrimovs, a new indoor tennis court with an inflatable cover was built. The transition from the building to the indoor courts and the newly created grandstands at the end of the house was built [58]. The parking lot in the NW part of the territory was renovated. 


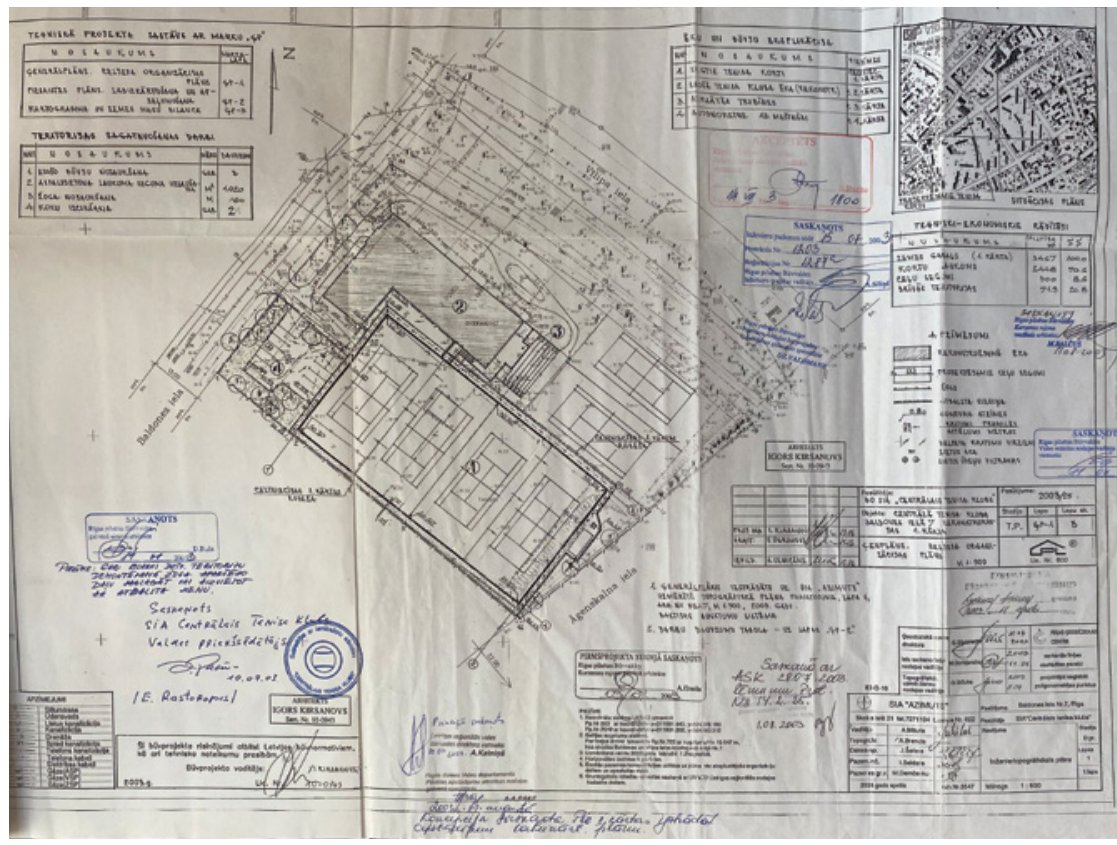

Figure 22. Spatial plan at 7 Baldones Street (2003).
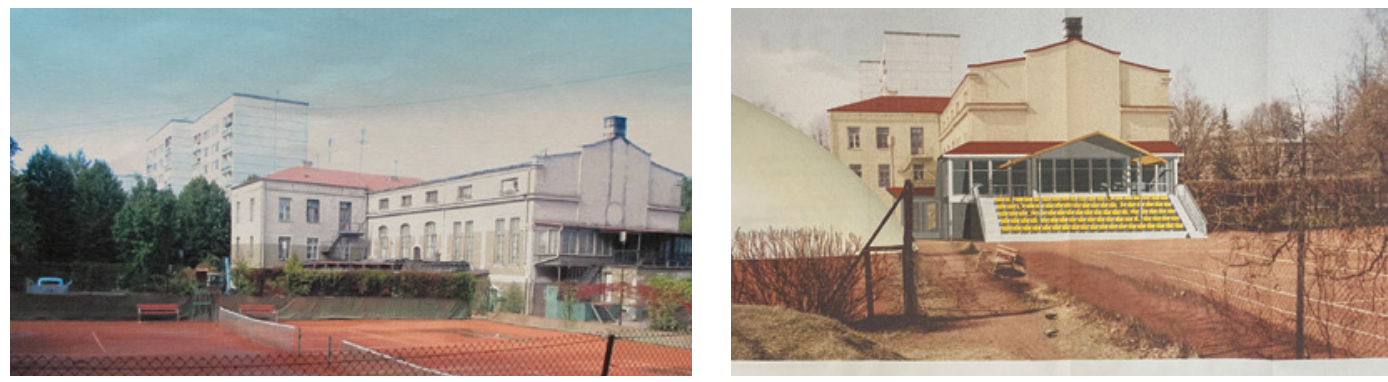

Figure 23. View of the building at 7 Baldones Street from Āgenskalna Street, reconstruction of the stands (2003).

In 2009, an architect, RTU graduate (1992) Normunds Babāns designed a cafe on the ground floor of the building. Construction works were performed by Ltd. «Demo Group» [59].

Further, the building is used not only for sports, but also for educational purposes. In 2010, under supervision of the architect Viktors Ugrimovs, the first and the second floors of the building, as well as the ground floor hall, were rebuilt for the needs of a private Russian Christian primary school [60]. A platform-type wheelchair lift from the ground to the first floor was built. After the reconstruction, the following premises are situated on the first floor: a hallway, a pupils' 
locker room and sanitary facilities, administration offices, two classrooms and a recreation hall with an exit to the external escape staircase. On the second floor, there is a corridor, a medical room, a pupils' locker room and a bathroom, a teachers' bathroom, an auxiliary room with an exit to the roof, two classrooms and a recreation hall with an exit to the external escape staircase. During the reconstruction, the windows in the first and second floors, as well as the fence of the territory along Baldones Street were replaced. The plan also included renovation of the facade.
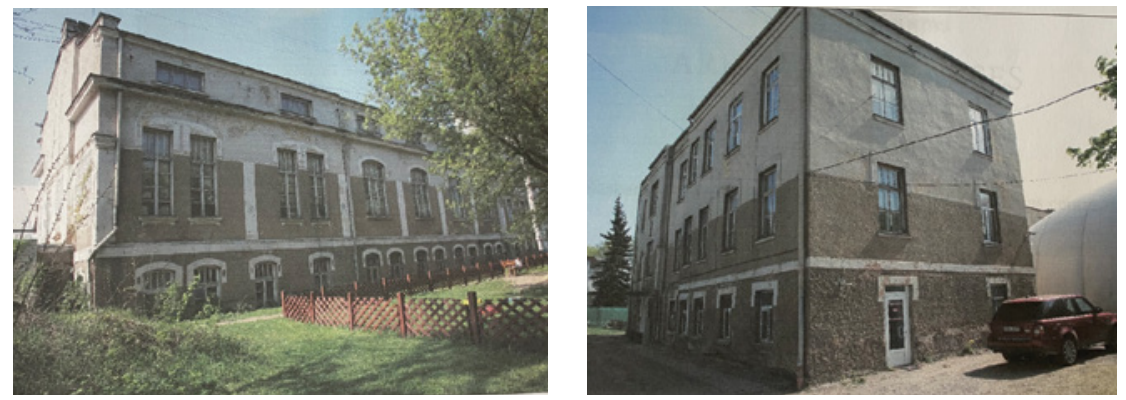

Figure 24. The building at 7 Baldones Street before reconstruction (2009).

In 2010, an elevator was built in the building. In 2011, a renovation project was developed, which envisioned reconstruction of the attic of the house, replacement of the roof and renovation of the facade of the house, allocating a place in the built attic for the administrative and economic needs of the private Russian Christian primary school [61]. In 2016, the project was implemented and facilities for the people with special needs were built on the first floor of the building [62].

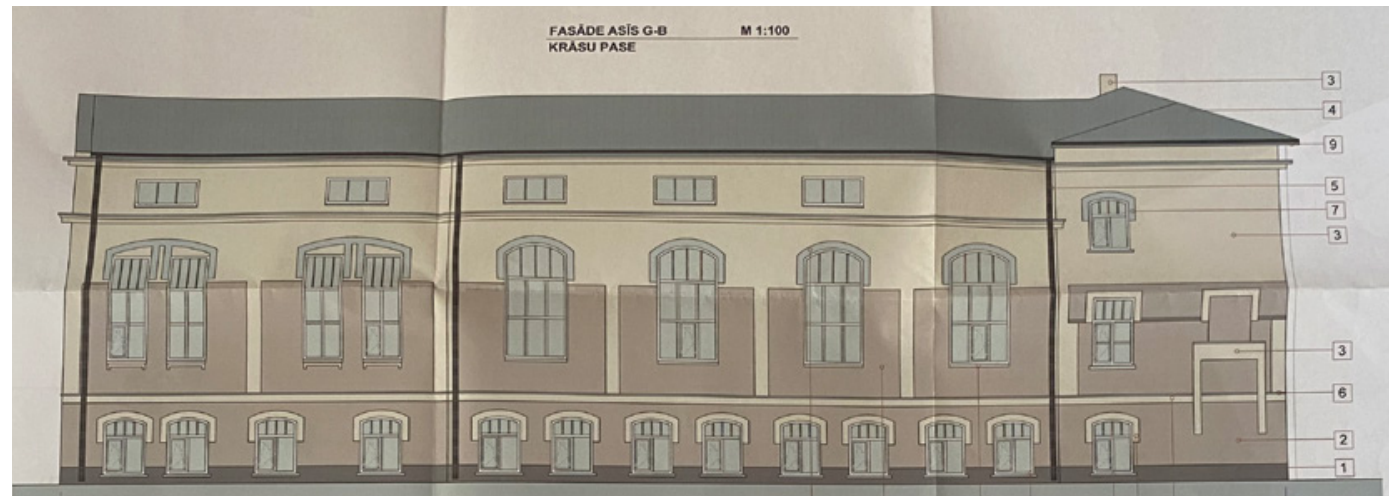

Figure 25. Renovation project of the facade of the building at 7 Baldones Street.

View from the Villipa Street. (2015). 


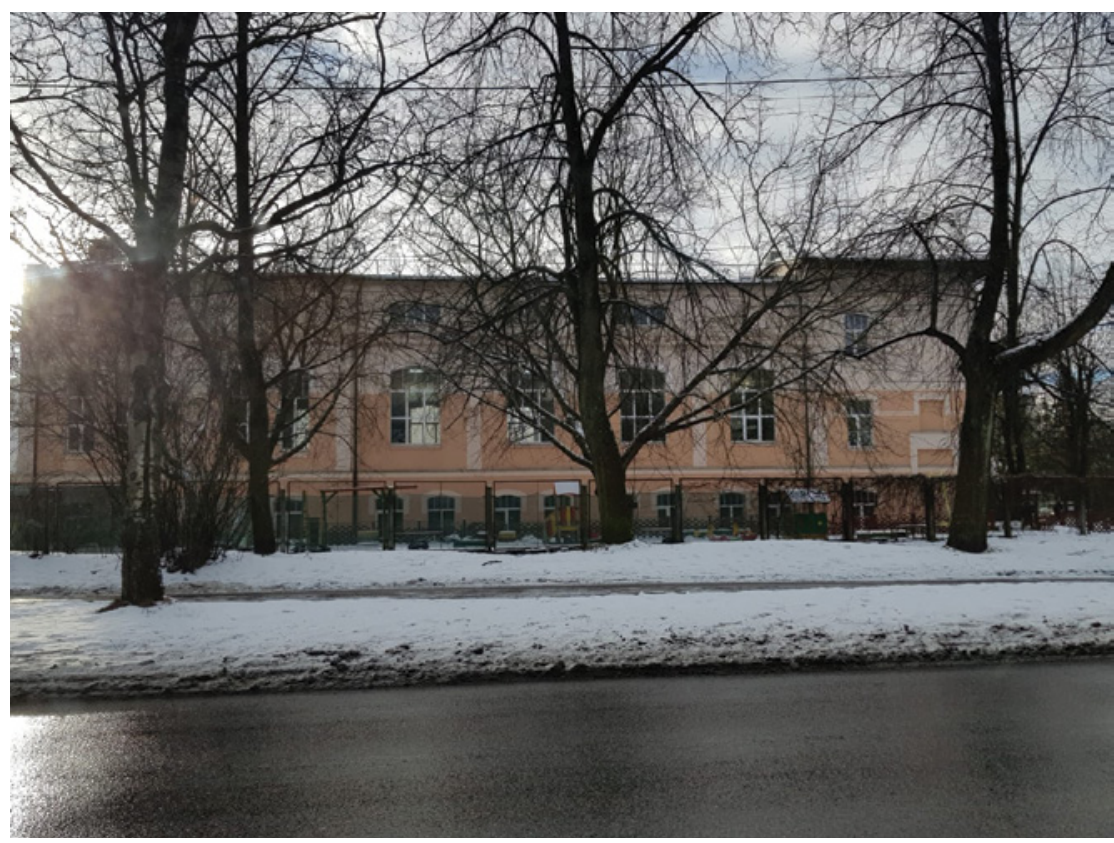

Figure 26. View of the building at 7 Baldones Street (2019).

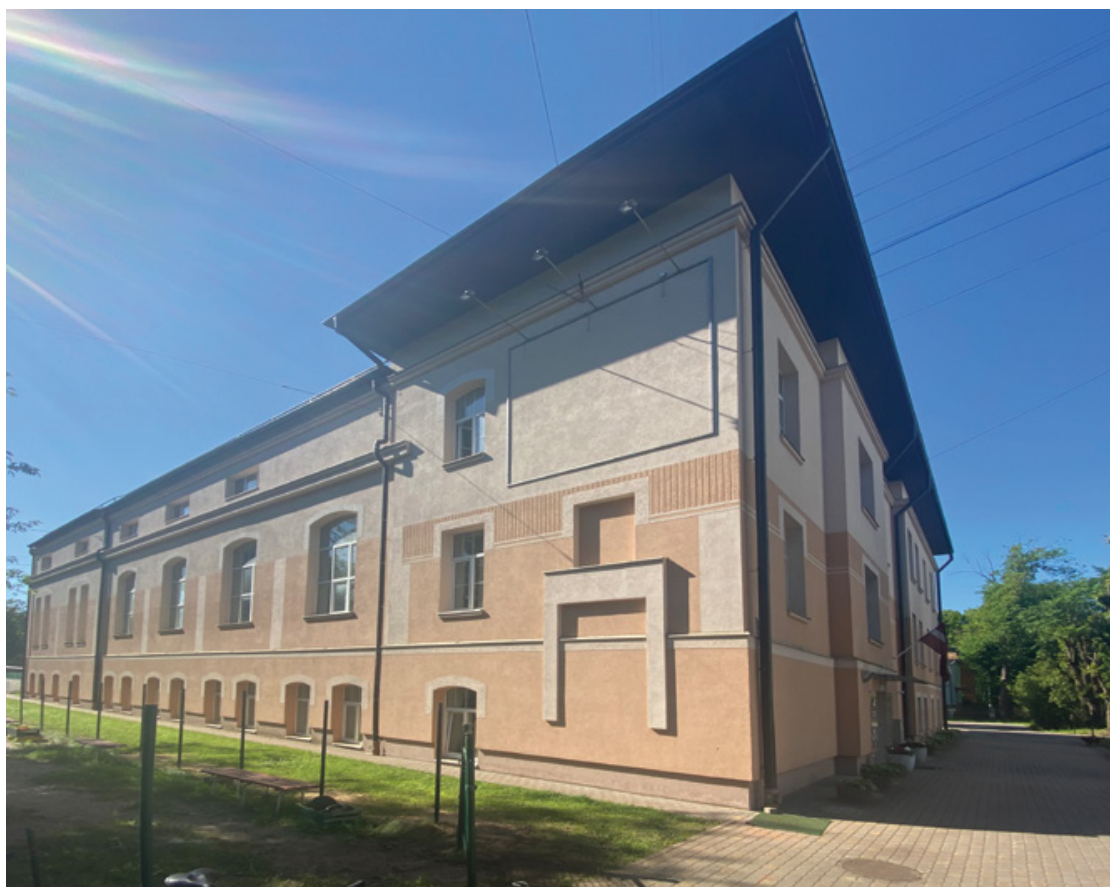

Figure 27. View of the building at 7 Baldones Street (2021). 


\section{Conclusions}

The activities of the Āgenskalns Gymnastics and Sports Society (1903-1939) are a vivid example of the Baltic-German sports culture, demonstrating contemporary thinking and understanding of physical culture and sports.

Erection of the Society building in 1910 according to architect L. Riemer's design with a gym at 11 Baldones Street changed the cultural environment in Āgenskalns, promoted the development of a socially responsible society, education and sports in Riga in the first half of the 20th century.

During the interwar period, the reconstruction and improvement works in the building (1927, 1935, 1936 and 1937), carried out by architects $H$. Blaus and A. Laukirbe, opened wide opportunities to organise public educational events and develop various sports - tennis, gymnastics, volleyball, handball, motorsport, etc.

During World War II, part of the movable property of the Society, including its flag, ended up in Poznan, Poland, where it irreversibly disappeared [4; p. 62]. After World War II, in the 1960s, the former ĀGSS property with a gym was used in the popularisation of sports, including tennis, which was ensured by the Tennis Club and the Children Sports School (CSS) of the Sports Society «Daugava» [63]. The facilities were used to promote and develop tennis, basketball, volleyball, martial arts, etc.

Since 1998, the sports hall of the Central Tennis Club (CTC) with the indoor and open tennis courts were in possession of the Ministry of Education and Science of the Republic of Latvia. On 9 July 2007, the ownership rights of the Ministry to the territory with a total area of 7331 square meters at 7 Baldones Street were terminated due to the sale of the property to Ltd. «Centrālais tenisa klubs» [64].

While the Riga City Council continued discussing the changes in the spatial plan with the local residents in 2019, the residents of Ägenskalns and the tennis community collected signatures to keep the sports centre at 7 Baldones Street. In 2019, Ltd. «Centrālais tenisa klubs» (CTC) applied for permission to change the status of the local land-use and ordered a local plan to prevent the construction of the shopping centre «Lidl» [65].

As a result of protests of Ägenskalns residents against the change of the sports function in CTC, on 4 September 2019, the National Cultural Heritage Board decided to include the $\bar{A} G S S$ building with its adjacent territory in the list of state protected cultural monuments as a location of historical events of neighbourhood significance in Riga [66]. 


\section{REFERENCES}

[1] Ošinš, I. Latvijas un latviešu sportiskie sasniegumi kā kultūras fenomens. Latvieši un Latvija (atb. red. V. Hausmanis, M. Kūle). Rīga: LZA, 2013, IV sēj. 619. lpp.

[2] Rechwenschafts-Bericht des Rigaer Turnvereins fuer das Jubilaeumsjahr 1912. Riga, 1912, S. 18.

[3] Sportvereine. Rigasches Adressbuch 1909. Riga: Adolf Richter, 1909, S. 34, 273., 278.

[4] Alsleben, H. O. Chronik der Familie Alsleben mit Nebenlinien, Teil I. Episoden und Geschichten aus dem Leben der Familie. S. 55-58, 60, 62, 65.

[5] Die Turnabteilung des Hagensberger geselligen Vereins. Rigasche Rundschau, 12. Mai 1903, Nr. 106, S. 5.

[6] Die Turnabteilung des Hagensberger geselligen Vereins. Duena Zeitung, 9. Mai 1903, Nr. 104, S. 5.

[7] Āgenskalna Vingrošanas un sporta biedrības statūti, nama iegādes un citi dokumenti. LNA LVVA 1615. f., 4. apr., 7397. l., 11., 13., 15., 30.,40, 45.-48., 57. lp.

[8] Āgenskalna Vingrošanas un sporta biedrības dokumenti. LNA LVVA 3724. f., 1 apr. 8070. 1., 18., 32, 33, 54. lp.

[9] Wettturnen des Rigaer Turnvereins. Duena Zeitung, 28. Mai 1904, Nr. 118, S. 5.

[10] Gruendung einer Schuetzengesellschaft in Hagensberg. Duena Zeitung, 25. Oktober 1907, Nr. 248, S. 3.

[11] Der Hagensberger Turn- und Sport-Verein. Baltische Post, 14. Februar 1913, Nr. 38, S. 3.

[12] 25 Jahre Hagensberger Turn- und Sportvereien. Riga am Sonntag, 12. Februar 1928, Nr. 9, S. 6.

[13] Eroeffnung der Paddelsektion. Rigasche Rundschau, 4. Mai 1933, Nr. 100, S. 7.

[14] Āgenskalna Vingrošanas un sporta biedrības darbības, inventāra iegādes un likvidācijas dokumenti. LNA LVVA 3235. f., 5. apr., 22. l, 2.-3., 7. lp.

[15] Āgenskalna Strēlnieku biedrības statūtu registrācija, 1923. gads. LNA LVVA 3724. f., 1. apr., 12178. 1., 11., 12., 27. lp.

[16] Āgenskalna Strēlnieku biedrības dokumenti. LNA LVVA 3724 f., 1. apr., 8072. l, 5. lp.

[17] Āgenskalna Slidkalna biedrības likvidācijas dokumenti. LNA LVVA 1799 f., 1 apr. 1 l., 24. lp.

[18] Schwechheimer H., Neumann A. u. a. Hagensberg ohne Wintersport. Rigasche Rundschau, 22 Dezember 1925, Nr. 288, S. 6.

[19] L. Sports. Latvijas Kareivis, 1927. gada 26. novembris, Nr. 266, 3. Ipp.

[20] Sport-Propaganda-Woche. Rigasche Rundschau, 28. Februar 1927, Nr. 47, S. 6.

[21] Āgenskalna vingrošanas un sporta b-ba. Sporta Pasaule, 1938. gada 18. novembris, Nr. 568, 9. lpp. 
[22] Basketbolu veicinās arī provincē. Brīvā Zeme, 1936. gada 13. novembrī, Nr. 259, 16. lpp.

[23] Āgenskalna Vingrošanas un sporta biedrība.Valdības Vēstnesis, 1938. gada 3. maijs, Nr. 98, 8. lpp.

[24] Schmied-Kowarcyk, R. «Prases dreier Sportvereine». Auszuge aus den Lebenserinnerungen. Jahrbuch des baltischen Deutschtums 1985. Luneburg, Munchen: Carl-Schirren-Gesellschaft, 1984, S. 118.

[25] Līgums par vācu tautības Latvijas pilsoṇu pārvietošanu uz Vāciju. Valdības Vēstnesis, 1939. gada 30. oktobrī, Nr. 247, 4.-7. lpp.

[26] Likvidētās sporta organizācijas. Fiziskā Kultūra un Sports, 1940. gada 1. janvāris, Nr. 1, 33. lpp.

[27] Āgenskalna Vingrošanas un sporta biedrības likvidācijas lieta. LNA LVVA 3724. f., 1. apr., 8073. l., 1., 11., 44. lp.

[28] Paziñojums. Valdības Vēstnesis, 1939. gada 7. novembris, Nr. 253, 8. lpp.

[29] Āgenskalna Vingrošanas un sporta biedrības dokumenti. LNA LVVA 3724. f., 1. apr., 8071. 1., 1., 22., 24., 27., 31., 33., 34. lp.

[30] Rīt ceḷā dosies otrs vāciešu transports. Brīvā Zeme, 1939. gada 17. oktobris, Nr. 236, 11. lpp.

[31] Āgenskalna Vingrošanas un sporta biedrības nama izmantošanas dokumenti, 1940. g. LNA LVVA 3724. f., 1. apr., 10715. 1., 21. lp.

[32] Rīgas aizsargu pulks izmanto Āgenskalna vingrotavu. Fiziskā Kultūra un Sports, 1940. gada 1. janvāris, Nr. 1, 21. lpp.

[33] Aizsargu vingrotāji izcīnīs Valsts prezidenta balvu. Jaunākās Zingas, 1940. gada 24. aprīlis, Nr. 92, 3. lpp.

[34] Latvijas meistarsacīkstes vingrošanā. Fiziskā Kultūra un Sports, 1940. gada 1. janvāris, Nr. 1, 27. lpp.

[35] Der Hagensberger Turn- und Sport-verein. Duena Zeitung, 4. Dezember 1904, Nr. 277, S. 5.

[36] Āgenskalna Vingrošanas un sporta biedrības likvidācijas dokumenti. LNA LVVA 3724. f.,1. apr., 8076. 1., 2., 3., 5. lp.

[37] Grundsteinlegung. Baltische Post, 20. April 1910, Nr. 88, S. 3.

[38] Album Academicum des Polytechnikums zu Riga, 1862-1912. Riga: Jonck \& Poliewsky, 1912, S. 486.

[39] Āgenskalna Vingrošanas un sporta biedrības ēkas plāns. LNA LVVA 231 f., 6. apr., 7972. l., 11., 13., 17., 28., 30., 34., 56. lp.

[40] Āgenskalna Vingrošanas un sporta biedrības ēkas plāns un citi dokumenti. LNA LVVA 2769. f., 1. apr., 4211. l., 3., 9. lp.

[41] Eine neue Turnhalle in Riga. Rigasche Zeitung, 15. November 1910, Nr. 263, S. 5.

[42] Galīgi piešksirtās rūpniecības iestādes, aug̣̦u dārzi un t. t. Zemes Ierīcības Vēstnesis, 1927. gada 21. oktobris, Nr. 250, 6. lpp.

[43] Rīgā būs jaunas telpas tenisa spēlei. Jaunākās Ziṇas, 1936. gada 8. oktobrī, Nr. 229, 12. lpp.

[44] Vakar beidzās pirmais tenisa turnīrs zem jumta. Sporta Pasaule, 1937. gada 8. februārī, Nr. 352, 4. lpp. 
[45] Ēkas Baldones ielā 7 katlu telpas, centrālapkures, ventilācijas un kanalizācijas izbūve. Rīgas Būvvaldes arhīvs (turpmāk - RBA) 157. grunts, 60. grupa, 9266. lieta.

[46] Odiṇš, Z. Ziema vēl tālu... Padomju Jaunatne, 1949. gada 17. novembris, Nr. 226., 6. lpp.

[47] Gatavoties ziemai, paaugstināt sporta techniskos rezultatus. Padomju Jaunatne, 1950. gada 30. novembris, Nr. 234, 1. lpp.

[48] Lūsis, J. Vissavienības meistarsacīkstes tenisā. Padomju Jaunatne, 1951. gada 17. oktobris, Nr. 204, 4. lpp.

[49] Mežavilks, Z., Stumbris, E., Liepiṇš, I. Tumši traipi. Sports, 1960. gada 15. decembris, 4. lpp.

[50] Austriṇš, A., Pḷavnieks, G. Nams iet bojā. Sports, 1962. gada 20. decembris, Nr. 148., 3. Ipp.

[51] Sporta zāles piebūve namam Baldones ielā 7. RBA 156., 157. grunts, 60. grupa, 9135. lieta, 1. lp.

[52] Strobs, J. Spēka zari. Padomju Jaunatne, 1962. gada 26. augusts, Nr. 168, 3. lpp.

[53] Stadionu atklās svētdien. Rìgas Balss, 1964. gada 8. maijs, Nr. 108, 4. lpp.

[54] Zilgalvis, L. Kur vējš dzenāja smiltis. Sports, 1964. gada 14. maijs, Nr. 56, 2. lpp.

[55] Centrālā tenisa kluba ēkas Baldones ielā rekonstrukcija, 1. kārta. RBA, 156. grunts, 60. grupa, bez numura.

[56] Centrālā tenisa kluba iekšējā plānojuma izmaiṇu izpildprojekts. RBA, 157. grunts, 60. grupa, 62207. lieta.

[57] Centrālā tenisa kluba rekonstrukcija, 2. kārta, RBA, 157. grunts, 60. grupa, 83733. lieta.

[58] Centrālā tenisa kluba rekonstrukcija, 2. kārta, RBA, 157. grunts, 60. grupa, 82991. lieta, 4. lp.

[59] Centrālā tenisa kluba Baldones ielā 7 rekonstrukcijas projekta izmainuu projekts, RBA, 157. grunts, 60. grupa, 82997. lieta.

[60] Ēkas Baldones ielā 7 2. un 3. stāva rekonstrukcija privātās Krievu kristīgās skolas vajadzībām, RBA, 157. grunts, 60. grupa, 105923. lieta.

[61] Ēkas Baldones ielā 7, Rīgā bēniṇu stāva rekonstrukcija, RBA, 157. grunts, 60. grupa, 110924. lieta.

[62] Ēkas Baldones ielā 7, Rīgā bēniṇu stāva rekonstrukcija (legalizācija), Būvprojekts, RBA, 157. grunts, 60. grupa, 133517. lieta.

[63] Fizkultūrieša kalendārs 1961.-1988. gadiem. Rīga: LVI, 1961-1988.

[64] [Rīgas pilsētas Vidzemes priekšpilsētas tiesas Zemesgrāmatu nodaḷa. Rīgas pilsētas zemesgrāmatas nodalījums Nr. 31084. Kadastra numurs: 0100060 0157, adrese: Baldones iela 7, Rīga.

[65] Āgenskalna iedzīvotāji nobremzē «Lidl» veikalu Baldones ielas tenisa kortu vietā [tiešsaiste]. https://jauns.lv/raksts/zinas/318705agenskalna-iedzivotaji-nobremze-lidl-veikalu-baldones-ielas-tenisakortu-vieta [skatīts: 30.06.2021].

[66] Nacionālās kultūras mantojuma pārvaldes lēmums Nr. 08-09.2/4230 2019. gada 4. septembrī. 


\section{SOURCES OF ILLUSTRATIONS}

Figure. 1. Āgenskalna Vingrošanas un sporta biedrības ēkas plāns un citi dokumenti. LNA LVVA 2769, 1. apr., 4211. 1., 23. lp.

Figure 2. Āgenskalna Vingrošanas un sporta biedrības dokumenti. LNA LVVA 3724. f., 1 apr. 8070. 1., 18. lp.

Figure 3. Alsleben, H. O. Chronik der Familie Alsleben mit Nebenlinien, Teil I. Episoden und Geschichten aus dem Leben der Familie.

Figure 4. Babetes Alslebenes kundzes /Frau Babett Alsleben/privātais arhīvs.

Figure 5. Alsleben, H. 0. Chronik der Familie Alsleben mit Nebenlinien, Teil I. Episoden und Geschichten aus dem Leben der Familie.

Figure 6. Āgenskalna Vingrošanas un sporta biedrības ēkas plāns un citi dokumenti. LNA LVVA 2769. f., 1 apr., 4211. l., 3. lp.

Figure 7. Raimunda Kovarčika pase. LNA LVVA 2996. f., 10. apr., 38508. 1., 5. lp. Figure 8. Āgenskalna Vingrošanas un sporta biedrības ēkas plāns. LNA LVVA 231. f., 6. apr., 7972. 1. lp.

Figure 9. Āgenskalna Vingrošanas un sporta biedrības ēkas plāns. LNA LVVA 231. f., 6. apr., 7972. 1. lp.

Figure 10. Āgenskalna Vingrošanas un sporta biedrības ēkas plāns. LNA LVVA 231. f., 6. apr., 7972. 1., 10. lp.

Figure 11. Āgenskalna Vingrošanas un sporta biedrības statūti, nama iegādes un citi dokumenti. LNA LVVA 1615. f., 4. apr., 7397. l., 57. lp.

Figure 12. Āgenskalna Vingrošanas un sporta biedrības ēkas plāns. LVA LVVA 231. f., 6. apr., 7972 l., 10. lp.

Figure 13. Āgenskalna Vingrošanas un sporta biedrības ēkas plāns. LNA LVVA 231 f., 6 apr., 7972 1., 1. lp.

Figure 14. Āgenskalna Vingrošanas un sporta biedrības dokumenti. LNA LVVA 3724. f., 1. apr., 8076. 1., 1. Ip.

Figure 15. Āgenskalna Vingrošanas un sporta biedrības dokumenti. LNA LVVA 3724. f., 1. apr., 8076. 1., 1. lp.

Figure 16. Ēkas Baldones ielā 7 katlu telpas, centrālapkures, ventilācijas un kanalizācijas izbūve. RBA 157. grunts, 60. grupa, 9266. lieta, 59., 60. lp.

Figure 17. Sporta zāles piebūve namam Baldones ielā 7. RBA 156., 157. grunts, 60. grupa, 9135. lieta.

Figure 18. Centrālā tenisa kluba ēkas Baldones ielā rekonstrukcija, 1. kārta. RBA 156. grunts, 60. grupa, bez numura.

Figure 19. Centrālā tenisa kluba iekšējā plānojuma izmaiṇu izpildprojekts. RBA 157. grunts, 60. grupa, 62207. lieta.

Figure 20. Centrālā tenisa kluba rekonstrukcija, 2. kārta. RBA 157. grunts, 60. grupa, 83733. lieta.

Figure 21. Centrālā tenisa kluba rekonstrukcija, 2. kārta. RBA 157. grunts, 60. grupa, 83733. lieta.

Figure 22. Centrālā tenisa kluba rekonstrukcija, 2. kārta. RBA 157. grunts, 60. grupa, 82991. lieta, 4. lp. 
Figure 23. Centrālā tenisa kluba rekonstrukcija, 2. kārta. RBA 157. grunts, 60. grupa, 83733. lieta.

Figure 24. Ēkas Baldones ielā 7 2. un 3. stāva rekonstrukcija privātās Krievu kristīgās skolas vajadzībām. RBA 157. grunts, 60. grupa, 105923. lieta

Figure 25. Ēkas Baldones ielā 7, Rīgā bēniṇu stāva rekonstrukcija (legalizācija), Būvniecības iecere. RBA 157. grunts, 60. grupa, 133514. lieta.

Figure 26. Foto - Lauma Jaunzeme.

Figure 27. Foto - Ilze Gudro.

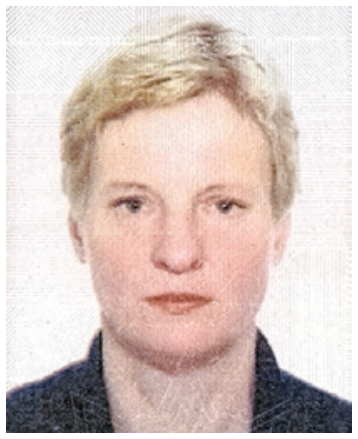

RITA APINE, Mg. paed., Leading Researcher at the Latvian Sport Museum. Co-author of a number of publications - a collection of books and articles on Latvian sports and the most outstanding personalities. Research interests - history of Latvian sports and research of athletes' curricula vitae.

Address: 9 Alksnāja Street, Riga, LV-1050, Latvia Phone: +37167225127

E-mail: rita.apine@sportamuzejs.lv

Rita Apine

\section{Āgenskalna Vingrošanas un sporta biedrības darbība un nams Baldones ielā 7}

Āgenskalna Vingrošanas un sporta biedrība bija viena no lielākajām un pazīstamākajām vācbaltiešu sporta organizācijām 20. gadsimta pirmajā pusē. Tajā darbojušies dažādu profesiju sporta entuziasti, tostarp inženieri. Sporta dzīvē nozīmīgs bija biedrības 1910. gadā uzceltais nams Rīgā, Baldones ielā 7, kas līdz mūsdienām vairākkārt pārbūvēts. Pētījumā rodams bagātīgs materiāls par biedrību un tās namu līdz vācbaltiešu izceḷošanai 1939. gadā. Izmantojot Latvijas Nacionālā arhīva Latvijas Valsts vēstures arhīva (LNA LVVA) dokumentus un preses materiālus, Rīgas Būvvaldes arhīva dokumentus, kā arī Latvijas Sporta muzeja krājumu, atklāti agrāk nezināmi fakti.

Atslēgas vārdi: Āgenskalna Vingrošanas un sporta biedrība, Baldones iela 7, arhitekti Leopolds Rīmers, Haralds Blaus, Alfrēds Laukirbe. 